\title{
Derivatives Market's Payment Priorities as Financial Crisis Accelerator
}

\section{Citation}

Mark J. Roe, The Derivative Market's Payment Priorities as Financial Crisis Accelerator, 63 Stan. L. Rev. 539 (2011).

\section{Published Version}

http://www.stanfordlawreview.org/sites/default/files/articles/Roe-63-Stan-L-Rev-539.pdf

\section{Permanent link}

http://nrs.harvard.edu/urn-3:HUL.InstRepos:30011626

\section{Terms of Use}

This article was downloaded from Harvard University's DASH repository, and is made available under the terms and conditions applicable to Open Access Policy Articles, as set forth at http:// nrs.harvard.edu/urn-3:HUL.InstRepos:dash.current.terms-of-use\#OAP

\section{Share Your Story}

The Harvard community has made this article openly available.

Please share how this access benefits you. Submit a story.

Accessibility 
ISSN 1936-5349 (print)

ISSN 1936-5357 (online)

\title{
HARVARD
}

JOHN M. OLIN CENTER FOR LAW, ECONOMICS, AND BUSINESS

\author{
THE DERIVATIVES MARKET'S \\ PAYMENT PRIORITIES AS \\ FINANCIAL CRISIS ACCELERATOR
}

Mark J. Roe

Discussion Paper No. 700

$06 / 2011$

Harvard Law School

Cambridge, MA 02138

This paper can be downloaded without charge from:

The Harvard John M. Olin Discussion Paper Series: http://www.law.harvard.edu/programs/olin_center/

This paper is also a discussion paper of the

John M. Olin Center’s Program on Corporate Governance. 
JEL ClASSIFICATIONS: G20, G28, G32, G33, G38, K22

\title{
THE DERIVATIVES MARKET’s PAYMENT PRIORITIES AS FINANCIAL CRISIS ACCELERATOR
}

\begin{abstract}
Mark J. Roe*
Chapter 11 bars bankrupt debtors from immediately repaying their creditors, so that the bankrupt firm can reorganize without creditors' cash demands shredding the bankrupt's business. Not so for the bankrupt's derivatives counterparties, who, unlike most other secured creditors, can seize and immediately liquidate collateral, readily net out gains and losses in their dealings with the bankrupt, terminate their contracts with the bankrupt, and keep both preferential eveof-bankruptcy payments and fraudulent conveyances they obtained from the debtor, all in ways that favor them over the bankrupt's other creditors. Their right to jump to the head of the bankruptcy repayment line, in ways that even ordinary secured creditors cannot, weakens their incentives for market discipline in managing their dealings with the debtor because the rules reduce their concern for the risk of counterparty failure and bankruptcy. If derivatives counterparties and financial repurchase creditors, who are treated similarly well in bankruptcy, were made to account better for counterparty risk, they would be more likely to insist that there be stronger counterparties on the other side of their derivatives bets, thereby insisting for their own good on strengthening the financial system. True, because derivatives counterparties bear less risk, nonprioritized creditors bear more and those nonprioritized creditors thus have more market-discipline incentives to assure themselves that the debtor is a safe bet. But the derivatives markets' other creditors-such as the United States-are poorly positioned either to consistently monitor the derivatives debtors well or to fully replicate the needed market discipline. Bankruptcy policy should harness private incentives for counterparty market discipline by cutting back the extensive advantages Chapter 11 and related laws now bestow on these investment channels. More generally, when we subsidize derivatives and similar financial activity via bankruptcy benefits unavailable to other creditors, we get more of the activity than we otherwise would. Repeal would induce these burgeoning financial markets to better recognize the risks of counterparty financial failure, which in turn should dampen the possibility of another AIG-, Bear Stearns-, or Lehman Brothers-style financial meltdown, thereby helping to maintain systemic financial stability. Repeal would end the de facto bankruptcy subsidy of these financing channels. Yet the major financial reform package Congress enacted in response to the financial crisis lacks the needed changes.
\end{abstract}

* Professor, Harvard Law School. Thanks go to Barry Adler, Douglas Baird, Martin Bienenstock, Albert Choi, Isaac Corré, Andrew Feldstein, Seth Grosshandler, Bruce Haggerty, Emily Hoort, Marshall Huebner, Howell Jackson, Christian Johnson, Louis Kaplow, Jonathan Lipson, Lynn LoPucki, Helen Lu, Stephen Lubben, Hal Novikoff, Michael Pereira, Craig Pirrong, Morgan Ricks, Hal Scott, Michael Simkovic, David Skeel, Holger Spamann, Richard Squire, René Stulz, George Triantis, Manuel Utset, Marco Ventoruzzo, William Widen, and workshop and conference participants at Bocconi University, Columbia Law School, Harvard Law School, St. John’s Law School, and the World Bank for comments on a prior draft; and Viral Acharya, Lucian Bebchuk, John Coates, Allen Ferrell, Lori Fife, Jesse Fried, Ronald Gilson, Jeffrey Gordon, Rocco Huang, Geoffrey Miller, Harvey Miller, Jeremy Stein, and Elizabeth Warren for conversations on the subject. 


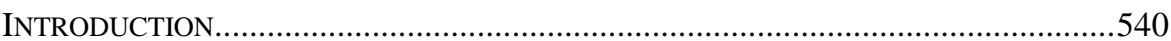

I. CHAPTER 11 SUPERPRIORITIES FOR DERIVATIVES AND REPOS .........................546

A. The Code .........................................................................................546

B. The AIG, Bear, and Lehman Failures in Light of the Code.........................548

1. AIG ..............................................................................................549

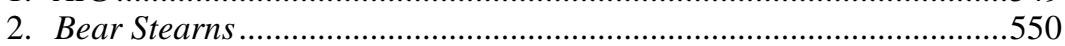

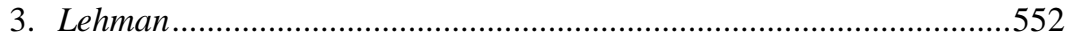

II. THE CORE BANKRUPTCY ISSUE: CODE-INDUCED DisinCENTIVES TO

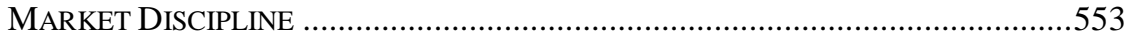

A. Incentives and Disincentives for Market Discipline .................................553

1. Counterparties often have needed skills, but limited incentives..........554

2. Exposed creditors have incentives, but limited skills ...........................554

3. The United States of America as missing creditor ............................557

4. The quandary of the bystander creditor ...............................................557

B. The Code-Induced Weakening of Market-Discipline Mechanisms.............558

1. Market discipline by counterparty monitoring .................................558

2. By raising prices ..........................................................................559

3. By dealing only with strong counterparties........................................559

4. By reducing exposure to a single counterparty...................................559

5. By substituting into stronger financing structures .............................560

6. By moving from overnight repos to longer-term financing .................560

7. By setting better margin coverage, earlier ..........................................561

8. By discouraging knife's-edge, systemically dangerous financing .......561

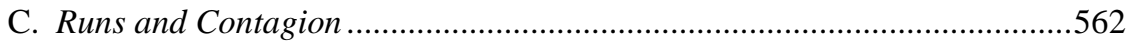

1. The analytic bidding to date ..............................................................562

2. AIG: collateral calls, runs, and private lenders' refusal to lend..........563

3. Credit contagion................................................................................564

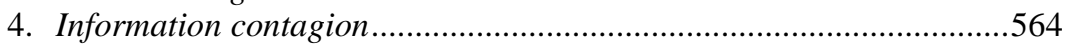

5. Collateral contagion ....................................................................566

III. Why CONTRACT CANNOT SOLVE COUNTERPARTY RISK ..................................566

A. Contractual Reaction and Its Limits................................................568

1. Financial covenants as partial solution ...........................................568

2. The necessary incompleteness of contract: the United States as de facto guarantor .............................................................................5.56

B. The Regulatory Reaction Needed .............................................................569

1. Reshaping the Bankruptcy Code's safe harbors ...............................569

2. Justified exceptions for the derivatives and repo markets..................570

IV.COUNTERARGUMENTS FROM COUNTERPARTIES .............................................572
A. Would Repeal Change Derivatives Market Incentives? ...........................572
B. The Unnecessary Asset? .............................................................................575
C. Financial Necessity: Are Derivatives and Repos Like Banking? .................577
D. Preserving Priority................................................................................578

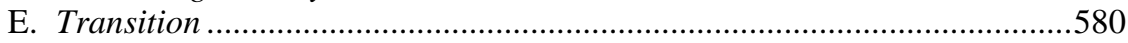

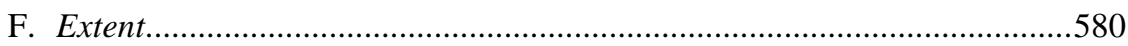

V. WHAT THE DODD-FRANK FINANCIAL REFORMS DO AND FAIL TO DO..............581

A. Dodd-Frank: Nothing on Bankruptcy Superpriorities ...............................581

B. A Derivatives Exchange: Many Eggs, One Basket...................................581

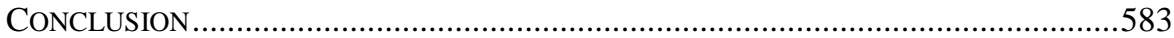

\section{The DeriVAtiVes Market’s Payment Priorities As FinANCIAL}




\section{CRISIS ACCELERATOR}

\section{(C) 2011. MARK J. ROE. ALL RIGHTS RESERVED}

\section{INTRODUCTION}

The AIG, Bear Stearns, and Lehman Brothers failures were at the heart of the 2008-2009 financial crisis and economic downturn. Some said their failures sparked a financial panic, others that it exacerbated the downturn. Some said their failures transmitted financial troubles emanating elsewhere in the economy in a way that brought the underlying economic damage to a head. ${ }^{1}$ Here, I show that the Bankruptcy Code's favored treatment of these firms' massive derivatives and financial repurchase (repo) contracts facilitated the firms' failures, by undermining market discipline in those markets in the years before these firms failed.

The Bankruptcy Code did so by sapping the failed firms' counterparties' incentives to account well for counterparty risk-the risk that their financial trading partner would fail (as AIG, Bear, and Lehman eventually did). Policymakers at the highest levels expected private monitoring to substitute for public monitoring, perhaps unaware that bankruptcy rules reduced those private incentives. Alan Greenspan, who chaired the Federal Reserve, extolled the derivatives players' "strong incentives to monitor and control [counterparty risk] ... . [P]rudential regulation is supplied by the market through counterparty evaluation and monitoring rather than by authorities. ... [P]rivate regulation generally is far better at constraining excessive risk-taking than is government regulation." 2 As late as 2008, Greenspan praised "counterparties' surveillance" as "the first and most effective line of defense against fraud and insolvency." "JPMorgan," he said, "thoroughly scrutinizes the balance sheet of Merrill Lynch before it lends. It does not look to the Securities and Exchange Commission to verify Merrill's solvency.”3

We now know that such scrutiny was not thorough. Worse, in the end, the financial sector relied on the government for far more than verifying counterparty solvency, obtaining the Federal Reserve's and U.S. Treasury's cash to bail out the seriously insolvent.

1. Compare Thomas Ferguson \& Robert Johnson, The God that Failed: Free Market Fundamentalism and the Lehman Bankruptcy, 7 Economists' VoICE 1, 5 (2010), with John H. Cochrane \& Luigi Zingales, Lehman and the Financial Crisis, Wall ST. J., Sept. 15, 2009, at A21.

2. Alan Greenspan, Chairman, Fed. Reserve Bd., Remarks at the 2003 Conference on Bank Structure and Competition (May 8, 2003) (transcript available at http://www.federalreserve.gov/boarddocs/speeches/2003/20030508/default.htm); see Benjamin M. Friedman, Two Roads to Our Financial Catastrophe, N.Y. Rev. Books, Apr. 29, 2010, at 27.

Counterparties are the two parties to the contract. A contract for the sale of goods has a buyer and a seller, the counterparties. In the derivatives and repo markets, each counterparty typically buys and sells related obligations. Counterparty risk is the risk not of the contract itself (e.g., that interest rates move adversely), but that the contracting partner (the counterparty) is unable to pay.

3. Alan Greenspan, The Age of Turbulence 257 (2008). 
I show here that bankruptcy priority perniciously weakens market discipline in the derivatives and repo markets because the stronger counterparties know that they often enough will be paid even if their derivatives or repo counterparty fails. Were the Bankruptcy Code superpriorities not so broad, the failed firms' financial trading partners would have anticipated that they might not be paid if they had weak counterparties that failed. Understanding this, they would have been further incentivized to lower their exposure to a potential failure of Lehman, AIG, or Bear. Were the superpriorities not in the Code, each failed firm would itself have been incentivized to substitute away from their own risky, often overnight financing and toward a stronger balance sheet to better attract trading partners. Were the superpriorities not in the Code, the three firms' counterparties would have had reason to diversify away from some trades with the failed firms into trades with other financial firms. Were the superpriorities not in the Code, the extra risk borne by counterparties would be more accurately priced and, at the higher pricing, we'd have had less systemically risky activity. Together, those incentives to market discipline should have made each of these three firms less financially central and less interconnected. They would likely have had less superpriority debt. The financial system would have been more resilient.

These bankruptcy-based problems are not small. When Bear failed, a quarter of its capital came from the repo market via short-term, often overnight, borrowings. ${ }^{4}$ Without the Code's priorities, such a precarious capital structure would not have been viable. When AIG failed, its excessive credit default derivatives exposure destabilized it further. Without the Code's priorities for AIG's derivatives trading partners, such a precarious position for AIG would not have been so easily viable. Without the Code's priorities, AIG's counterparties would have had reason to worry earlier about AIG's potential to fail to make good on its derivatives obligations.

That is the downside of favoring the derivatives and repo markets in bankruptcy. But risk-free investments with a very high bankruptcy priority have major efficiency potential. Superpriority investment channels can lower information and negotiation costs for lenders and borrowers, facilitating financing flows that otherwise would not occur. Such efficient flows, if they could proceed without imposing costs on other parties or on the financial system and the economy, deserve a supportive legal framework. The problem, though, is that the major superpriority vehicles come packaged with systemically dangerous consequences, because systemically central institutions disproportionately use the bankruptcy-safe package. And, while a low-risk channel is supported, some major part of that risk ends up borne by the United States as backer of major, too-big-to-fail financial institutions. If we could separate efficient flows from systemically dangerous flows - and then allow the first, while restricting the second - we could strengthen finance in two dimensions. But if we cannot separate the efficient from the dangerous, we need to choose. Given our recent experience, the best policy choice with the information at hand is to strengthen

4. See The Bear Stearns Cos., Quarterly Report (Form 10-Q), at 5 (Apr. 14, 2008) [hereinafter Bear Stearns Form 10-Q], available at http://www.sec.gov/Archives/edgar/data/ 777001/000091412108000345/be12550652-10q.txt. 
the system in the critical dimension of systemic stability. To do so, we need to sharply cut back the priority package.

Overall, these are not just local financial structures that failed: When the financial crisis began in June 2007, we had \$2.5 trillion in overnight repos, while the aggregate insured bank deposits in the United States were not even twice that. ${ }^{5}$ The overall derivatives market was backed by $\$ 4$ trillion of collateral in December 2008, and just one type of derivatives market - the interest rate swap, explained below—grew to more than $\$ 400$ trillion. ${ }^{6}$

Figure 1 illustrates the market's explosive growth in the dozen years preceding the financial crisis. In 1994, the private business debt and interest rate derivatives markets were about the same size, at $\$ 13$ trillion for the former and $\$ 11$ trillion for the latter. In the subsequent fifteen years, the business debt market tripled to \$34 trillion, while the interest rate derivatives market increased nearly fortyfold to $\$ 430$ trillion. Combine the overnight repo market with the collateralized portion of the derivatives market, and we have a financial market bigger than the government-insured banking system. If there's a failure in these markets, the initial governing rules come from the Bankruptcy Code.

5. For total repo, see Figure 2 and supporting sources. For total insured deposits, see FDIC, STATISTICS AT A GLANCE (2007), available at http://www.fdic.gov/bank/statistical/ stats/2007jun/FDIC.pdf.

6. INT'L SWAP \& DeRIVATIVEs Ass'N, ISDA MARKET SURVEy (2010) [hereinafter 2010 ISDA MARKET SURVEY], available at http://www.isda.org/statistics/pdf/ISDA-Market -Survey-annual-data.pdf; INT’L SWAPS \& DERIVATIVES Ass’N, ISDA MARGIN SURVEY 2009, at 3 (2009), available at http://www.isda.org/c_and_a/pdf/ISDA-Margin-Survey-2009.pdf. In an interest rate swap, one party trades a floating interest rate for a fixed rate on, say, \$100 million of debt that neither party has borrowed or lent. The $\$ 100$ million "notional" amount is often reported as the transaction's size. At year-end 2008, that notional amount totaled $\$ 400$ trillion. But it is the smaller interest payment obligation that is being swapped, with the collateral transferred even smaller. That lower collateral amount goes into the text's still-big $\$ 4$ trillion number. 
FIGURE 1

Growth in the Markets for Interest Rate Derivatives and for All Private Business Debt, 1994-20097

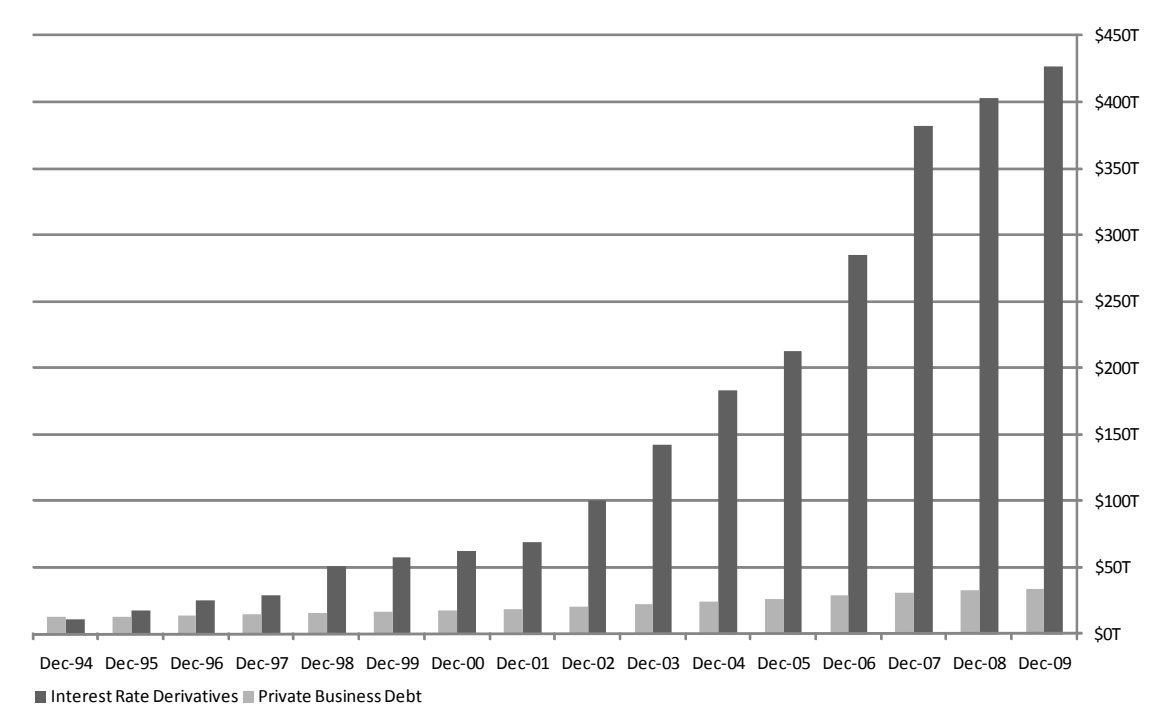

A roadmap for this Article: In Part I, I describe the counterparties' Codebased advantages. Although several are conceptually sound in that the Code accommodates potentially useful financial channels, most go beyond wise bankruptcy and financial policy. Several otherwise-sensible local accommodations become unsound public policy when we account for the potential systemic damage they entail.

In Part II, I show how the Code's advantages sap counterparties' incentives for market discipline when dealing with the weak debtor. The Code thereby discourages financial resiliency. Understanding how this happens adds to important prior work on the derivatives priorities. Prior work focused on the problem of financial contagion and a bank-run-style collapse of a derivatives-heavy entity, with the Code priorities facilitating a run and collapse.

Run analysis is important, and I analyze it further. But, regardless of run and contagion analysis, I seek to shift policymakers' focus from the moment just prior to the institution's collapse to the months and years well before collapse. Better bankruptcy law could create better incentives than it does now for counterparties to more efficiently structure their trillion-dollar derivatives and repo books so as to avoid an eventual counterparty collapse, rather than to mitigate the consequences of an actual collapse. This enhanced market discipline is where, I argue, lie the major benefits of reducing the bankruptcy priorities for the derivatives and repo markets. Indeed, reversing the weakened market dis-

7. See Bd. of Governors of the Fed. Reserve Sys., Flow of Funds Accounts of THE UNITED STATES 9 (2010), available at http://federalreserve.gov/releases/z1/20100917/ z1.pdf (growth in private business debt); 2010 ISDA MARKET SURVEY, supra note 6 (growth in derivatives). 
cipline is important regardless of whether the discipline is sapped by superpriority or by ordinary priority. We'd want to confront the Code's impact regardless.

In Part III, I extend this ex ante, market-discipline analysis by analyzing why a financially central firm's other creditors usually cannot adjust their contracts to resolve the Code's current major disincentives to counterparty monitoring in the derivatives context. Code priorities that reduce the derivatives counterparties' risks and market-discipline incentives thereby raise risks that the firm's other creditors face. Risk is transferred, not eliminated. Conceptually, those other creditors can reduce their exposure to a risky debtor, raise their prices, or watch the debtor more closely. But the relevant players here are not always the best informed and best skilled at understanding and reducing resulting risks because they often are not themselves derivatives and repo professionals. The largest affected creditor is the United States as de facto guarantor of weakened but too-big-to-fail financial debtors. It can provide prudential regulation, not market discipline. The United States has no contract, unless we conceptualize the Bankruptcy Code rules as its de facto contract. If we do so, that contract needs to be revised going forward.

Hence, one channel to the 2008 bailouts ran through the Bankruptcy Code. While other causes are likely to have been more important, the bankruptcy rules' impact on derivatives players' incentives when structuring their transactions needs further analysis.

In Part IV, I examine the core arguments favoring derivatives and repo priorities. Although several bankruptcy advantages for each are functional and ought to be kept, the full range is far too broad. I also add two negative, perhaps serious, macroeconomic implications of derivatives priorities. The Code's superpriorities were first justified as measures to reduce contagion. But, as has been shown before, they can spread contagion as well as contain it. Worse, the superpriorities also facilitate information contagion and encourage simultaneous liquidation of debtors' assets in a financial crisis. Both difficulties were strongly in play in the financial crisis. I bring forward reasons why the Code's superpriorities exacerbate both.

Information contagion arises when lending markets discover they do not understand counterparty financial strength and stop lending until they acquire enough information; bankruptcy superpriority discourages early counterparty information acquisition. Collateral-value contagion arises when financiers simultaneously sell similar assets, depressing their prices if the market is not fully liquid, thereby compromising the immediate value of their assets. The lowering of immediate asset value induces other lenders to the debtor to declare a default, seize collateral, and liquidate that collateral.

The Bankruptcy Code allows derivatives and repo creditors, but not most others, to immediately seize and sell off their collateral, and to demand and keep eve-of-bankruptcy collateral, thereby facilitating collateral contagion. These two effects-information contagion and collateral-value contagion-are run-enhancing consequences of the superpriority rules we have. I show the logical links between the Code's payment priorities and these two crisisexacerbating difficulties.

I then conclude. The Bankruptcy Code's safe-harbor superpriorities for derivatives and repurchase agreements are ill conceived. Like others before me, I 
am skeptical that the bankruptcy priorities are wise, but my skepticism comes from a different analysis, one based primarily on the counterparties' ex ante incentives. The Code priorities decrease the derivatives players' ex ante market discipline. The de facto bankruptcy subsidies for these financing channels expand the market beyond what it otherwise would be. Without the priorities, the players would have reason to substitute into safer financing channels. But noting this incentive alone is not enough to justify a change in policy, because lower market-discipline, monitoring, and substitution incentives for some creditors correspondingly mean greater incentives for the other creditors. If the others react well, contractually or otherwise, there is little cost to the enhanced priority of derivatives. I show that for many systemically important financial institutions, their other creditors cannot react well because they are poorly informed or because they, like the United States, are distant and contingent.

The Code thereby encourages risky, knife's-edge financing, which, when pursued in financially central firms, transfers risk to the United States as the ultimate guarantor of the key firms' solvency. We get more derivatives and repo activity than we would otherwise. Financial resiliency is drained; market discipline, weakened.

\section{CHAPTER 11 SUPERPRIORITIES FOR DERIVATIVES AND REPOS}

Repos and derivatives differ financially from one another, but enjoy the same advantages under the Code. A financial repurchase agreement-called "repo" in that market-is a sale of a financial instrument, such as a treasury bill, with the seller promising to buy that asset back, often the next day. The agreed repurchase price is a little higher than the sale price, with the difference being the de facto interest. The instrument sold is usually called the collateral, as the transaction is functionally a loan. Repos are typically used to finance a firm, often a financial firm.

Derivatives trade financial outcomes such as those of changing currency rates or of long-term for short-term interest rates. Some derivatives are effectively guarantees of financial performance of a third party. One party (often AIG in the years prior to the financial crisis) promises to pay a risk-avoiding party if a third party defaults on its financial obligations. Derivatives typically transfer risks.

These two financing channels, once backwaters for financial flows, became mainstream in recent decades. They are treated more favorably in bankruptcy than are other loans, trades, and investments. Some of the analysis and Code impact applies to one of the finance channels, some to the other, some to both.

\section{A. The Code}

A failing firm's bankruptcy filing strips its creditors of rights that they would otherwise have. First, the Bankruptcy Code bars the debtor's creditors from suing the debtor for repayment, bars them from trying otherwise to collect debts due from the bankrupt, and — if the creditors are secured—bars them from immediately seizing or liquidating their security. Second, creditors who are repaid on an old loan in the ninety days before bankruptcy often must return those payments to the bankrupt, thereby allowing all creditors to share in that 
value. Third, ordinary creditors, unlike derivatives counterparties, lack the right without court permission to set off as many of their own debts due to the debtor against debts due from the debtor. Fourth, bankrupts can recover prebankruptcy fraudulent conveyances-which arise when the debtor sells its own assets for less than their fair value-for the benefit of all of the bankrupt's creditors. Fifth, the Code limits most creditors' and suppliers' rights to terminate contracts with the bankrupt. Sixth, creditors cannot terminate their contracts with a bankrupt if the firm files to reorganize its finances in Chapter $11 .^{8}$

For creditors holding derivatives and repurchase agreements with the bankrupt, each rule is reversed to favor the derivatives and repo creditors. First, these counterparties can immediately collect on their debts at the beginning of a bankruptcy while other creditors cannot. Second, they need neither return eveof-bankruptcy preferential payments on old debts nor give back preferential collateral calls that other creditors must return. Third, they have broader setoff rights that allow them to escape handing over money they owe to the debtor. Fourth, they are exempt from most fraudulent conveyance liability. Fifth, derivatives counterparties can choose whether or not to terminate contracts. Sixth, they need not suffer the debtor's typical bankruptcy option to assume or reject the underlying contract. ${ }^{9}$ The total impact of these exemptions and special rules is to give the favored creditors a superpriority over disfavored creditors.

Bankruptcy sticklers may object to calling these priority provisions, and they are formally correct. The Code sets forth priorities in 11 U.S.C. § 507 and $\S 726$, and those basic priorities are unaffected by being a derivatives creditor. The derivatives and repo benefits operate by exempting the bankrupt's derivatives- and repo-holding creditors from baseline rules (such as the stay against creditors taking action against the debtor or its assets, an exemption that allows them to obtain and liquidate collateral in ways that other creditors cannot), insulating them from typical creditor liability rules (such as fraudulent conveyance and preference rules), and giving them more rights (such as to terminate unfavorable contracts). But because their exemptions' total impact is to

8. See 11 U.S.C. § 362(d) (2006) (automatic stay); id. § 547 (requiring return of preferences); id. § 362(a)(7) (setoffs); id. § 548 (fraudulent conveyance liability for mismatched consideration); id. $\S \S 365,541$ (c)(1) (debtor's contract right is property of the estate); id. $\S 365(\mathrm{e})(1)$ (providing for unenforceability of ipso facto clauses that make the debtor's bankruptcy a default under its contract). Bankruptcy aficionados will see exceptions and qualifications, such as the need for secured-creditor "adequate protection" and the multiple steps for preference recovery. For textual brevity, I state the general rules summarily.

9. See id. §§ 362(b)(17), 362(b)(27), 560 (derivatives and repo players' ability to liquidate collateral in their possession); id. § 546(g), (j) (exemption from preference rules); id. $\S \S 553(\mathrm{a}), 560$ (wider option to set off); id. § 546(g), (j) (exemption from constructive fraudulent conveyance liability); id. §§ 555, 559-561 (ability to terminate repos, swaps, and master netting agreements); id. (exemption from debtor's typical § 365 option to affirm or reject). These apply in both Chapter 7 liquidations and Chapter 11 reorganizations. Not all of these favorable rules are unwise. Most, though, are too broad. See Part III.B.2 on the cutback's appropriate scope.

Termination rights are quite valuable when the counterparty is secured. In that situation, the counterparty can take advantage of two derivatives exemptions from the Code, by terminating the contract and then seizing the security to satisfy any damages that the bankrupt owes it upon termination. Other creditors can neither terminate the contract nor seize the security. Two-thirds of the derivatives contracts were collateralized (that is, secured) in 2007. René M. Stulz, Financial Derivatives: Lessons from the Subprime Crisis, MiLKEN INST. REV., First Quarter 2009, at 58, 65. 
pay those favored first, or pay them more, in substance they accord the favored creditors a superpriority status. Hence, it is legitimate to call these exemptions shorthand quasi priorities, as I do here. The Code favors the derivatives and repo players with exemptions, insulations, and special treatment. They do better and get more due to those exemptions, insulations, and special treatment.

The exceptional treatment accorded derivatives and repos in bankruptcy is recent. Regulators and lobbyists sought the exceptions when the derivatives market was young, partly to clarify some treatment issues, partly due to effective lobbying of the derivatives players, and partly due to a regulatory belief that such financial markets were sufficiently beneficial to warrant special treatment. Regulators and market players argued that the potential for one failure of a major derivatives dealer to cascade through the financial system justified superpriority. I skeptically examine several of the public-spirited arguments, particularly the clarification and contagion perspectives, below. ${ }^{10}$

My normative point is not that the baseline bankruptcy rules for nonderivatives creditors are uniformly wise and that the derivatives exceptions are uniformly unwise; several baseline rules could be improved if Congress overhauled the Code. ${ }^{11}$ The point is that we have two sets of bankruptcy rules-one for derivatives counterparties and one for everyone else-and having two sets of rules is unwise. One set limits creditors' asset seizures from the bankrupt firm. The second set exempts seizures and accords extra priorities to creditors holding financial contracts called "derivatives" or "repurchase agreements." It is no surprise that sophisticated finance players seek to structure their transactions as derivatives or repo agreements, because it protects them. By doing so, the superprioritized counterparties have fewer incentives to ration their dealings with financially weak debtors.

These negative incentives can perniciously affect the debtor itself, its other creditors, and, ultimately, the economy. The 2010 Dodd-Frank financial reforms ought to have cut back the derivatives and repo priorities. Those cutbacks still need to be made. Making them would reduce the possibility of another meltdown in the pattern of AIG, Bear Stearns, and Lehman.

\section{B. The AIG, Bear, and Lehman Failures in Light of the Code}

This is not the place to describe the financial crisis and the collapse of AIG, Bear, and Lehman. Good narratives can be found elsewhere. ${ }^{12}$ Nor is this Article the place to examine the legal, economic, and political problems that induced and accelerated the financial crisis. Weakened bank capital rules, regulatory lapses, rating agency mistakes, transactional complexity, ${ }^{13}$ and the poli-

10. See infra Part II.C.

11. For example, there may be reason to make some basic rules more creditor friendly than they now are (I offer no view on that here), but there is little reason and much cost to doing so only for one favored group of creditors and not for others.

12. E.g., William D. Cohan, House of Cards (2009); Lawrence G. McDonald with Patrick Robinson, A Colossal Failure of Common Sense (2009); Henry M. PAulson, JR., ON THE BRINK (2010); GiLlian TETT, FoOL’s Gold (2009).

13. See Comm. on Capital Mkts. Regulation, The Global Financial Crisis (2009), available at http://www.capmktsreg.org/pdfs/TGFC-CCMR_Report_\%285-26-09\% 29.pdf; Ross Levine, An Autopsy of the U.S. Financial System: Accident, Suicide, or Negli- 
cy and underlying politics of subsidizing the subprime housing market all were important. Instead, I cull core features from the three megafirms' failures to see how derivatives' superadvantages in Chapter 11 weakened market discipline and contributed to the firms' eventual demise. These Code-induced disincentives to greater market discipline exacerbated other problems, made their own contribution to the crisis, and are not technically difficult to ameliorate.

1. $A I G$

Consider AIG, the huge insurer. AIG was a big player in the credit default swap market, where it assured others that it would pay up if a third firm failed to make good on its own debt. When AIG failed in September 2008, its financial affiliate was obligated on $\$ 400$ billion of credit default obligations, when AIG's total equity was only about $\$ 100$ billion. Some of these credit default swaps functioned as guarantees of other companies' debts. Some had AIG guaranteeing the performance of mortgage pools, including those infamous subprime housing mortgages. ${ }^{14}$ AIG's counterparties depended on AIG to make good on the credit default swaps if their underlying investments in the mortgage pools or other companies' debts deteriorated.

Goldman Sachs was one of AIG's major trading partners. It had protected other investors in the mortgage market on about $\$ 14$ billion of securities, then purchased credit protection from AIG at a lower rate, profiting from the $\$ 50$ million difference. According to a former chief of AIG's financial products unit, in a postmortem: "It seems shocking to me that Goldman would become so exposed to AIG and kept doing deals with them and laying on the risk." 15 This suggests Goldman paid insufficient attention to the creditworthiness of its counterparty, AIG. But the risks that Goldman took in dealing with AIG are consistent with it expecting to have the derivatives priority in bankruptcy, which facilitated that risk taking. The Code priorities plausibly distorted Goldman's incentives as it dealt with AIG. ${ }^{16}$

AIG had earlier been a AAA, investment-grade risk, one of sufficiently high quality that its derivatives counterparties did not initially require it to post

gent Homicide, 2 J. FIn. ECon. PoL'y 196 (2010); Jonathan C. Lipson, Enron Rerun: The Credit Crisis in Three Easy Pieces, in Lessons FROM THE FinANCIAL CRISIS 43 (Robert W. Kolb ed., 2010); Michael Simkovic, Secret Liens and the Financial Crisis of 2008, 83 Ам. BANKR. L.J. 253 (2009).

14. See Matthew Philips, The Monster That Ate Wall Street, Newsweek, Oct. 6, 2008, at 46; Ben Levisohn, AIG's CDS Hoard: The Great Unraveling, BusinEssweEK (Apr. 6, 2009), http://www.businessweek.com/bwdaily/dnflash/content/apr2009/db2009044_488554 .htm.

15. Serena Ng \& Carrick Mollenkamp, Goldman Fueled AIG Gambles, WALL ST. J., Dec. 12, 2009, at B1. The AIG executive had left AIG before its mortgage-backed purchases began in earnest. Id.

16. See Office of the Special Inspector Gen. for the Troubled Asset Relief Program, Factors AfFecting EfForts to Limit Payments to AIG Counterparties 1617 (2009), available at http://www.sigtarp.gov/reports/audit/2009/Factors_Affecting_Efforts _to_Limit_Payments_to_AIG_Counterparties.pdf. But see Carrick Mollenkamp \& Serena Ng, Report Rebuts Goldman's Claim on AIG, WALL ST. J., Nov. 18, 2009, at C1 (stating that Goldman's collateral would not have fully protected the firm from AIG's collapse). Other explanations are possible. Goldman might have not understood the risk early enough. Credit agencies, for example, were late in downgrading AIG. 
collateral. It instead agreed "to post generous collateral if the value of the insured securities dropped or if its own credit rating fell." ${ }^{17}$ Creditors can find such contingent collateral posting promises to be unreliable in normal settings, because bankruptcy law often requires that the favored creditor return collateral posted by a failing firm if the firm goes bankrupt within ninety days of the posting. The AIG collateral post would ordinarily have been a voidable preference as a transfer on the eve of bankruptcy, out of the ordinary course of business, while the debtor was insolvent. The recipient could not keep the collateral, but would have to return it for all creditors' pro rata benefit.

But the Code's derivatives exemptions made AIG's promise to post collateral valuable. When AIG lost its AAA rating (as the value of its direct investments in subprime mortgages declined) its counterparties, such as Goldman, demanded large collateral postings, as their contracts contemplated. ${ }^{18}$ The collateral AIG paid over on the eve of its bankruptcy was conceptually a preference, one that bankruptcy law would ordinarily void and force the recipient to return to the bankrupt estate, so that all of AIG's creditors could share the collateral's value. Were the preference exemptions unavailable, Goldman would have had more incentive to structure safer AIG dealings early on, because it ought to have feared that it could not keep late-posted collateral.

AIG, on the eve of its failure, insisted that Goldman return several billion dollars of what AIG thought to be its own collateral overpayments to Goldman, as front-page newspaper headlines tell us. ${ }^{19}$ Had Goldman lacked the exceptions from rules barring preferences and fraudulent conveyances, its bargaining position would have been weaker, as AIG could have recovered the funds from Goldman in Chapter 11. Instead, Goldman did not have to, and in fact did not, return the money. ${ }^{20}$

\section{Bear Stearns}

Consider Bear Stearns, the huge investment bank and securities trader. Bear's immediate problem prior to its failure was that, like many investment banks, it extensively relied on repos to finance itself. Banks like Bear need

17. Henny Sender, AIG Saga Shows Dangers of Credit Default Swaps, FIN. TimES (London), Mar. 6, 2009, http://www.ft.com/cms/aa741ba8-0a7e-11de-95ed-0000779fd2ac .html.

18. See René M. Stulz, Credit Default Swaps and the Credit Crisis, 24 J. ECON. PersP. 73, 83 (2010).

19. See Gretchen Morgenson \& Louise Story, Testy Conflict with Goldman Helped Push A.I.G. to Precipice, N.Y. Times, Feb. 7, 2010, at A1.

20. See id. If ordinary preference law applied, the eve-of-bankruptcy collateral postings could have been attacked in a bankruptcy. (The relevant AIG affiliate, if in bankruptcy, could have pursued a separate contract claim if Goldman breached the contract it had with AIG via refusing to return an overposting.)

Goldman insisted that it was well protected without the government's eventual \$85 billion bailout of AIG. Uninvestigated is whether this self-protection claim could have been made accurately without the Code's derivatives exceptions for repayments that otherwise would have been voidable preferences.

AIG's credit default swap business was largely run through a London subsidiary. In an AIG bankruptcy, presumably the United Kingdom's substantially similar priority rules would have applied. (Bankruptcy in the United Kingdom is liquidation oriented. American bankruptcy is, derivatives excepted, reorganization oriented.) 
cash; Bear obtained much of its liquidity by selling its securities and promising to buy them back later, often the next day. Bear's sale with an obligation to repurchase functionally turned the transactions into short-term secured loans to Bear. And, because the overnight loans were typically rolled over, Bear's repo financing became de facto long-term financing, until Bear, in trouble, could no longer roll over its overnight borrowings. This kind of financing was common for securities firms and was "repeated day after day for some thirty years .... Goldman Sachs, Morgan Stanley, Merrill Lynch, Lehman Brothers, and Bear Stearns ... w[ere] always just twenty-four hours away from a funding crisis.",21

Bear's short-term, largely overnight borrowing was at the $\$ 100$ billion level. With $\$ 400$ billion in assets when it failed, a quarter of Bear's value was in the repo market, an amount eight times Bear's total equity capital at risk. ${ }^{22}$ This level had sharply increased from 1990, when Bear's net repo financing was only $7 \%$ of its total liabilities and only twice its equity. Congress added derivatives priorities to the Code over the last three decades, expanding them in 1982, 1984, 1994, 2005, and 2006. While it's hard to know exactly what caused what - a growing market calling forth supportive legislation or legislation helping the market to grow-Bear's financing counterparties would have had difficulty supporting Bear's short-term repo financings if they had lacked the Code's ever-expanding repo and derivatives advantages. ${ }^{23}$ And Bear was not alone: the portion of total investment bank assets financed by overnight repos doubled between 2000 and 2007. ${ }^{24}$ Bear was the one that failed, but the entire sector financed itself similarly.

Because Bear's repo counterparties could seize and sell their security, as they were exempt from the Code's stay against collateral liquidation after any potential filing to reorganize under Chapter 11, they were even less concerned with Bear's viability and liquidity than ordinary secured creditors, who are themselves Code-favored but not as extensively. Absent the superpriorities, Bear would not have been as able to finance a quarter of its total assets in the repo market for as long as it did, as easily as it did. ${ }^{25}$ Its repo lenders would have lent it less and charged it more. Bear's mix of borrowings would have

21. CoHAN, supra note 12, at 5. Short-term financing can make all those concerned more alert. But that does not justify subsidy via favored bankruptcy status.

22. See Bear Stearns Form 10-Q, supra note 4, at 5. While this is the number reported in the media, Bear's net repo position is more relevant, as it also bought securities subject to sale back. Its net position parallels its liability position alone. When it failed, its net repo position was nearly $20 \%$ of total liabilities and six times its equity.

23. When Bear failed, it had been using nonprime collateral for its repo contracts. It lost access to repo financing when the market would only take government securities for repos. See Peter Hördahl \& Michael R. King, Developments in Repo Markets During the Financial Turmoil, BIS Q. REV., Dec. 2008, at 37, 46. Prior to the 2005 Code amendments, only repos of treasuries and similar securities explicitly had superpriority.

24. Markus K. Brunnermeier, Deciphering the Liquidity and Credit Crunch 20072008, 23 J. ECON. PERSP. 77, 80 (2009).

25. Ordinary creditors, even secured creditors, can be called on to turn over property needed by the estate to reorganize. See 11 U.S.C. §§ 541-542 (2006); United States v. Whiting Pools, Inc., 462 U.S. 198 (1983). They may be protected in Code terms, but creditors frequently think they are not made financially whole. 
likely had to go longer-term, thereby better stabilizing the firm against reversals. ${ }^{26}$

\section{Lehman}

Consider Lehman Brothers, the long-lived investment bank. Prior to its collapse, Lehman owed J.P. Morgan about \$20 billion. Four days before Lehman's bankruptcy, J.P. Morgan froze \$17 billion of Lehman cash and securities that J.P. Morgan held, and then demanded $\$ 5$ billion more in collateral. ${ }^{27}$ Creditors cannot ordinarily seize and liquidate their collateral in Chapter 11, but instead must wait for the bankruptcy court to decide whether the assets are needed for a successful reorganization, in which case the Code requires that court determine that arrangements are in place to protect the creditor from deterioration in the collateral's value. ${ }^{28}$ Because of the exception from the Code's automatic stay for favored derivatives creditors, ${ }^{29}$ J.P. Morgan could immediately liquidate the collateral in Lehman's bankruptcy. ${ }^{30}$

The Code superpriorities put J.P. Morgan in a better position than standard secured creditors with ordinary loans, as ordinary lenders cannot immediately seize their security and would have risked that the bankrupt could recover from them their prebankruptcy benefits. ${ }^{31}$ Because Lehman's derivatives counterparties could grab value out from Lehman ahead of Lehman's other creditors, its other creditors lost more than they would have otherwise. ${ }^{32}$

The Reserve Fund was one of those other creditors. That fund, then the nation's oldest money market fund, owned $\$ 785$ million of Lehman commercial paper, effectively short-term IOUs running from Lehman to the Reserve Fund. The Reserve Fund's loss on the Lehman paper was enough to induce a run of

26. And Bear's counterparties revalued Bear subprime collateral just before Bear failed. See Jason Hsu \& Max Moroz, Shadow Banks and the Financial Crisis of 2007-2008, in The BAnking Crisis HandBook 39, 49 (Greg N. Gregoriou ed., 2010).

27. See Darrell Duffie, The Failure Mechanics of Dealer Banks, 24 J. Econ. PersP. 51, 67-68 (2010); Susanne Craig \& Robin Sidel, Crisis on Wall Street: J.P. Morgan Made Dual Cash Demands, Wall ST. J., Oct. 8, 2008, at C2; Iain Dey \& Danny Fortson, JP Morgan 'Brought Down' Lehman Brothers, Sunday Times (London), Oct. 5, 2008, at 1; David Teather, Banking Crisis: Lehman Brothers: JP Morgan Accused over Bank's Downfall, GUARDIAN (London), Oct. 6, 2008, at 11.

28. See 11 U.S.C. §§ 361-362.

29. See id. §§ 362(b)(17), 362(b)(27), 560.

30. In early March 2010, the Lehman bankruptcy examiner filed a report analyzing the Code status of the transactions. Shortly after he filed the report, Lehman and J.P. Morgan settled claims from these transactions on terms favorable to J.P. Morgan. Lehman paid J.P. Morgan a cash settlement and J.P. Morgan returned some unused, unsold, difficult-to-value collateral. See Lehman Settles Collateral Claims with JPMorgan, DEALBooK (Feb. 25, 2010), http://dealbook.nytimes.com/2010/02/25/lehman-settles-collateral-claims-with -jpmorgan; Linda Sandler, Lehman Brothers Examiner Files Sealed Report on Banks (Update2), BLOOMBERG (Feb. 9, 2010), http://www.bloomberg.com/apps/news?pid=20601103 \&sid=awa8w7ZOIhbY\#.

31. See 11 U.S.C. § 546(g), (j). A transfer for less than full value from a bankrupt in the two years before bankruptcy is prima facie a fraudulent conveyance, which the bankrupt estate can recover from the recipient.

32. The Reserve Fund could have faced problems just from the other creditors being secured, although the actual transfer sequence suggests a $\$ 5$ billion eve-of-bankruptcy preference to J.P. Morgan that benefited from the derivatives' exemption from preference law. 
redemption demands from the fund's shareholders, ending with the fund's collapse. ${ }^{33}$ It failed shortly after Lehman did, fanning financial panic.

Money market funds, like the Reserve Fund, invest in short-term securities and seek to maintain an asset value of $\$ 1.00$ per share to indicate their financial stability and near-bank-like safety. "Breaking the buck" is considered a shocking event in that financial sector and, when the Reserve Fund broke it, the Treasury felt compelled for a time to guarantee all money market funds during the financial crisis. ${ }^{34}$

While the Reserve Fund's collapse has been analytically linked to Lehman, Lehman's immediate impact on the fund's collapse is less critical than the ex ante problem of weakened market discipline. Someone had to lose money when Lehman failed. If not the Reserve Fund, then someone else. But if the superpriorities had not been in place when Lehman built its capital structure and derivatives portfolio, Lehman's derivatives and repo counterparties' incentives to insist upon a more stable Lehman would have been greater. And Lehman itself would have been incentivized to keep to a safer capital structure to encourage its counterparties to keep dealing with it at low cost.

This sapping of market discipline, which should be a central consideration in structuring this part of the Code but was not addressed in either the legislative deliberations or subsequent analyses, is the problem I focus on next.

\section{THE CORE BANKRUPTCY ISSUE: CODE-INDUCED DISINCENTIVES TO MARKET DISCIPLINE}

\section{A. Incentives and Disincentives for Market Discipline}

The Bankruptcy Code's core negative consequence from favoring derivatives contracts and repurchase agreements is to slacken the contracting parties' efforts to contain the risk of counterparty failure. The systemic impact of the superpriorities needs to be evaluated for two classes of financial events, which arise at different times: The first is to evaluate the superpriorities' impact when the system is suffering an ongoing crisis-when the question is whether the superpriorities dampen or exacerbate the financial crisis. The second is to assess their impact in the years before a financial crisis, when they can sap market discipline and thereby increase the chance that a financial crisis occurs.

33. See Press Release, The Reserve, A Statement Regarding the Primary Fund (Sept. 16, 2008), available at http://www.reservefunds.com/pdfs/Press\%20Release\%202008_0916 .pdf; see also Jeffrey N. Gordon \& Christopher Muller, Confronting Financial Crisis: DoddFrank's Dangers and the Case for a Systemic Emergency Insurance Fund, 28 YALE J. ON REG. 151, 164, 181 n.80 (2011); Marcin Kacperczyk \& Philipp Schnabl, When Safe Proved Risky: Commercial Paper During the Financial Crisis of 2007-2009, 24 J. ECON. PersP. 29, 40-41 (2010).

34. See Press Release, U.S. Dep’t of the Treasury, Treasury Announces Guaranty Program for Money Market Funds (Sept. 19, 2008), available at http://www.ustreas.gov/press/ releases/hp1147.html. 


\section{Counterparties often have needed skills, but limited incentives}

The priorities reduce counterparty risk, inducing stronger players to accept a higher, perhaps imprudently higher, level of derivatives and repo financing with weak counterparties. If they bore more risk of counterparty failure, they might demand better-capitalized counterparties. Or they would demand better counterparty portfolio information, so that they could better price that risk. ${ }^{35}$ They would charge the risky counterparty more and the sound one less. The weak counterparty would be incentivized to become financially stronger (so as to be charged less) and, at least to the extent prices rose, the parties would do less derivatives and repo business. The Code's superpriorities thereby undermine market discipline.

Derivatives lawyers advise their clients to be wary that a counterparty might fail. In a leading derivatives lawyer's guide for derivatives-dealing managers, the author implored firms to develop derivatives risk-management programs. ${ }^{36}$ These programs should include having senior people responsible and accountable, ${ }^{37}$ with manuals that indicate tasks and risk management. But those manuals presumably need not overly emphasize the fundamentals of counterparty risk, because, says the guide in a lawyer's sequence on "What the Pros Recommend" for risk management, counterparty risk is best handled by being sure that the bankruptcy superpriorities have been obtained. ${ }^{38}$ As finance people say, "Due to these credit enhancements, market participants commonly view interest rate swaps as free of counterparty default risk." ${ }^{39}$ The derivatives' lobbying organization is said to have been formed in the 1980s to find ways for the derivatives market to avoid counterparty risk. ${ }^{40}$

In the derivatives market's early days in the 1980s and early 1990s, before the full range of superpriorities became law, "it would be quite rare to see $\mathrm{a}[]$... derivatives transaction that did not involve Fortune 500 firms or top-tier financial institutions. Indeed,.... commercial and investment banks even formed AAA-rated subsidiaries to handle derivatives . ..." ${ }^{41}$ One must wonder whether derivatives' explosive growth during the past quarter century depended on their expanding exemptions from normal bankruptcy practice.

\section{Exposed creditors have incentives, but limited skills}

But, there's a rebuttal to the idea that superpriorities sap market discipline: Because the derivatives and repo counterparties bear less risk of debtor failure,

35. That is what Greenspan erroneously thought was happening in the derivatives and repo markets. See supra notes 2-3 and accompanying text.

36. See Philip McBride Johnson, Derivatives: A Manager's Guide to the World's Most Powerful FinANCIAL Instruments 47 (1999). Johnson wrote as a derivatives lawyer and former chair of the Commodity Futures Trading Commission, the market's main regulator.

37. See id. at 49 .

38. See id. at 115-16.

39. Michael Johannes \& Suresh Sundaresan, The Impact of Collateralization on Swap Rates, 62 J. Fin. 383, 383 (2007); accord Bruce Tuckman, FiXed Income Securities: TOOLS FOR TODAY'S MARKETS 388-90 (2d ed. 2002).

40. See Michael Lewis, The Big Short 48 n.*, 49 (2010).

41. Johnson, supra note 36, at 56 . 
the debtor's other creditors correspondingly bear more risk. One could mistakenly believe that the total level of incentives for market discipline and for risk rationing stays the same, as a sort of Modigliani-Miller irrelevance proposition. But this is not the case. ${ }^{42}$

The Code's priority modulation is unlikely to leave total monitoring incentives unaffected, because the other players in the failing financial firm's capital structure are too often poorly positioned either to monitor that firm or to wield other means of market discipline. Most importantly, the other players include the United States government as contingent guarantor of the liabilities of firms that are too big to fail. It is poorly positioned to fully replace market discipline via adequate prudential regulation.

\section{a. Commercial paper (Lehman)}

When it failed, Lehman had sold $\$ 4.8$ billion of its commercial paper. ${ }^{43}$ Like Bear, it heavily financed itself via repo. The unwillingness of the commercial paper market to roll over Lehman's obligations was a proximate cause of Lehman's failure. ${ }^{44}$ Commercial paper buyers operate on very small margins. They invest for the very short term, do not write financial covenants into their investments, and are not positioned to monitor their debtors in the finetextured manner of bank loan officers.

I do not assert that the commercial paper market has no market-discipline capacity, nor that the repo and commercial paper markets are sharply separate. Often they involve the same money market players, who sometimes "do repo" and sometimes buy commercial paper. Investors, especially mixed investors who buy both, do not always sharply sort out counterparty risk from collateral risk when investing. At the beginning of 2007, taxable money market funds like the Reserve Fund held on average a third of their portfolio in commercial paper, a sixth in repos. ${ }^{45}$

And, typically, commercial paper buyers do ultimately react to counterparty risk, but often not until it's too late for the failing firm to recover. When the commercial paper market comes to understand that the firm is failing, it refuses to roll over purchases of that firm's commercial paper when the paper comes

42. Modigliani and Miller showed that a firm's risks emanated from its underlying operations, not from how it sliced up its capital structure, absent transaction costs and benefits. Here, the risk of counterparty failure emanates from the counterparty's underlying business; if one creditor bears less risk, another takes on more. See Franco Modigliani \& Merton H. Miller, The Cost of Capital, Corporation Finance and the Theory of Investment, 48 АM. ECON. REV. 261 (1958).

43. Lehman Bros. Holdings Inc., Quarterly Report (Form 10-Q), at 24 (July 10, 2008) [hereinafter Lehman Form 10-Q], available at http://www.secinfo.com/d11MXs.t1C1k.htm \#1stPage.

44. See Int'L Monetary Fund et al., Guidance to Assess the Systemic IMPORTANCE OF FINANCIAL INSTITUTIONS, MARKETS AND INSTRUMENTS 19-22 (2009), available at http://www.imf.org/external/np/g20/pdf/100109a.pdf. Lehman lost access to other financing sources as well, and the coup de grâce came when "its clearing bank, JPMorgan, cut its credit line.” Id. at 19.

45. See Kacperczyk \& Schnabl, supra note 33, at 36; Adam Copeland, Antoine Martin \& Michael Walker, The Tri-Party Repo Market Before the 2010 Reforms 25, 37 (Fed. Reserve Bank of N.Y., Staff Report No. 477, 2010), available at http://www.ny.frb.org/ research/staff_reports/sr477.pdf. 
due. As happened for Lehman, the refusal to roll over then becomes a proximate cause of the firm's failure.

Commercial paper buyers will learn from their mistakes; presumably they now better understand the risks of buying paper from firms with large openended derivatives portfolios. Although their market discipline and reactive potential was, and is, hampered by the opacity of the derivatives market, ${ }^{46}$ they should adjust going forward either by demanding a premium or by avoiding excessive exposure to that market. Or, with potentially negative systemic effects, they may conclude that the best self-protection going forward is to get the superpriority benefits of repo protection.

\section{b. Unsecured policyholders (AIG)}

A large portion of an insurance company's creditors are unsecured policyholders. The Code's superpriorities could put them at risk if the insurance firm's affiliated financial products subsidiary fails and the insurance assets are not adequately segregated (or are not worth enough). Cross guarantees are (and were) common, and the businesses are hard to fully separate. ${ }^{47}$ Of course, policyholders are poorly positioned to monitor the insurer's derivatives portfolio, because too often they are small retail insurance consumers who lack the skills to evaluate the insurer's underlying investment portfolio. Realistically, the insurer's regulator would take over the entity and shield the policyholders. But this hardly improves the monitoring situation: the policyholders are saved, but the state insurance regulators are poorly placed to keep an eye on insurers' affiliates' derivatives risks day to day, much less to contain systemic risks to the American and world economies.

\section{c. Unsecured depositors and bank creditors (Citigroup)}

Big banks, as custodians of the nation's payments system, are the quintessential systemically vital financial institutions. Lowering their counterparties' risks raises the risks to depositors (and, eventually, to the depositors' government guarantor): if the bank lacks enough assets to pay off all of its creditors, the secured derivatives counterparties come first and the depositors second. Retail depositors are poorly placed to monitor a commercial bank's assets at all, much less understand and monitor a complex derivatives portfolio in the bank or an affiliate. ${ }^{48}$ In the end, it's again the regulator and government guarantor that count.

46. On opacity, see Frank Partnoy \& David A. Skeel, Jr., The Promise and Perils of Credit Derivatives, 75 U. CIN. L. REv. 1019, 1036 (2007); and Simkovic, supra note 13, at 271-75. Although better disclosure is the usual cure, the derivatives book may be inherently opaque. See Robert P. Bartlett, III, Inefficiencies in the Information Thicket: A Case Study of Derivative Disclosures During the Financial Crisis (Berkeley Cent. for Law, Bus. \& the Econ., Paper No. 1585953, 2010), available at http://www.ssrn.com/abstract=1585953.

47. See Richard Squire, Shareholder Opportunism in a World of Risky Debt, 123 HARV. L. REV. 1151, 1187-89 (2010). The insurer would not reorganize under Chapter 11, but its holding company and affiliates typically would.

48. Commercial banks do not reorganize in Chapter 11, but their affiliates traditionally do. FDIC resolution procedures today would have treated the derivatives contracts of a failed 


\section{The United States of America as missing creditor}

The most important Code-induced mismatch of market-discipline incentives and capacity is that coming from the United States as lender of last resort to the guaranteed and too-big-to-fail financial institutions. Compare the United States to the financially central firm's derivatives counterparties. The national government is typically distant from the scene until a crisis arises, has diffuse incentives, can face difficulties in hiring those with the relevant expertise, and is often politically constrained from being aggressive. Often the market players themselves influence government policy in their immediate favor. None of this is to say that the United States is passive or unable to deal with a specific firm, particularly once the government is alerted to a problem. But it is poorly positioned to monitor risk successfully on a firm-by-firm, day-to-day basis.

Moreover, even a fine regulator doesn't want to do the job alone. With the superpriorities in place and with too many of the other creditors of core financial institutions passive and government guaranteed, the United States has every reason to want market players to have strong market-discipline incentives to monitor and ration risk. The United States should want parallel private monitors with private incentives to do the job in tandem with the government.

The United States can best control its exposure by better overall prudential regulation ex ante, including capital and portfolio rules, and by fixing the bankruptcy rules so as to call forth more market discipline. Conceive of the Bankruptcy Code adjustments I recommend as one effective way that a regulator who is also a guarantor adjusts to a market that puts a heavy risk load on the government's shoulders. It harnesses the market. It incentivizes market discipline in aid of regulatory finesse.

\section{The quandary of the bystander creditor}

The impediments facing traditional lenders here are serious. Consider the quandary of traditional lenders to the derivatives-heavy debtor. Their debtor has a large, hard-to-value component, namely its derivatives book. Its derivatives counterparties are not overly concerned with their debtor's financial stability, because they protect themselves with the debtor's collateral, rather than with their understanding of the firm itself. In that setting, traditional lenders bear more risk but lack added capacity to understand the debtor's complex underlying condition because of the opacity of the debtor's increasingly large derivatives book. These traditional lenders need to compensate for their increased risk and their weakened capacity to assess that opaque risk. They hence have reason to substitute away from traditional financing and into the derivatives and repo components because they can best protect themselves via the Code's favored treatment of derivatives and repos, without needing to understand their counterparty's overall financial health well. A self-reinforcing engine can start up.

By inducing complexity and opacity, the Code does not help the financial system. That is, if private parties absorbed the costs of complexity and opacity

Citibank similarly to the way they're treated for other counterparties under the Bankruptcy Code. 
and still decided that the transaction is valuable, there's little public reason to intervene. But here we have the oddity that the Code grants private players superpriorities, but for private parties to obtain them, they must raise systemic costs by making the financial system more complex and more opaque. This is an unwise trade-off.

To be sure, the payment priorities do not end all incentives for counterparty monitoring. In practice, many favored derivatives trades are not fully collateralized. And the strong counterparty needs to know whether to demand more collateral when its counterparty is moving out of the money. That induces the strong counterparty to pay attention both to the contract and to collateral value, which can be a window into the counterparty's overall status. And some derivatives, such as credit default swaps, have a "jump-to-default" quality, by which the contract can become suddenly valuable (such as when a reference entity defaults and a large sum becomes due); these contracts put the strong counterparty at risk if the contract value rises suddenly and simultaneously with the decline of the weak counterparty's overall value.

Thus, while the situation is not black and white, and we lack empirical measures of most costs and benefits here, the incentives and directional push are clear: the Code reduces incentives for market discipline and increases incentives to use more of the Code-favored instruments.

\section{B. The Code-Induced Weakening of Market-Discipline Mechanisms}

Repeal of most superpriorities should make strong counterparties more vividly recognize that weak counterparties could fail. Strong counterparties should react with more rigorous market discipline by raising their prices, by reducing their exposure to weak counterparties, by using less of what would then become less strongly favored financing channels, and by insisting that their counterparties' financial structures be stronger. The changes are about what one should expect when eliminating a subsidy.

\section{Market discipline by counterparty monitoring}

Counterparty discipline could take several forms. The first is obvious and traditional: the strong counterparty watches the weak one's financial state, studies its finances, and assesses its derivatives and repo exposure.

True, a derivatives player's capacity, like that of a traditional lender, ${ }^{49}$ to directly assess the other side's overall value is diminished when the other side has an opaque, deep derivatives book. And economic theory suggests that firmby-firm monitoring is costly. Hence, while one should not overly rely on enhancing individualized counterparty monitoring capacity, the incentives issue is still crucial, as the incentives even for cheap monitoring, for better collective monitoring, and stronger overall market discipline are weak with superpriorities in place.

49. See supra Part II.A.4 (describing the quandary of the traditional lender). 


\section{By raising prices}

The second market mechanism is just as simple. Made to bear more risk, the stronger derivatives-trading players would have reason to raise their prices when trading with weaker ones. The raised prices would motivate the weak counterparties to be stronger, would lead trading to move to stronger counterparties, and would result in some trades not getting done-the derivatives market would shrink once counterparty risks were fully priced and the implicit subsidy removed.

\section{By dealing only with strong counterparties}

A third means of market discipline is also simple: the strong one only does business with well-capitalized counterparties. Some systemic financial weakness in 2007 and 2008 emanated from the fact that investment banks, such as Lehman and Bear, had thin equity layers of only about $3 \%$ of their total assets. ${ }^{50}$ Incentivized counterparties could have insisted on only doing business with counterparties having, say, equity of at least $5 \%$ of assets.

Oftentimes centralized assessment of counterparty risk is most efficient. Incentivized market players may lack the skills to evaluate counterparty risk, but they would then have the incentives to support strengthened centralized rating agencies and better overall prudential regulation, both of which were weak during the run-up to the financial crisis. ${ }^{51}$

\section{By reducing exposure to a single counterparty}

The derivatives market is strongly centralized, with five firms accounting for nearly $90 \%$ of the industry's net credit exposure. ${ }^{52}$ But if Congress altered the Code so that the counterparties were made to bear more counterparty risk, stronger firms could have more reason to diversify their range of counterparties if some of the central parties were neither rock solid nor fully government guaranteed. There would be more players with a smaller stake in this financial market.

The market's existing extended setoff rights also militate toward market concentration. To get more value from the currently bestowed setoff and preference rights, the derivatives dealer does better if it has its derivatives positions with a single counterparty than with many. Spreading the trades around to many counterparties would fritter away the extra value to derivatives players of the extended setoff. (If you have an unsecured in-the-money trade with $A$, and

50. See, e.g., Bear Stearns Form 10-Q, supra note 4, at 5; Lehman Form 10-Q, supra note 43 , at 5 .

51. "It is now much more common [post-Lehman], according to [the head of asset servicing at Société Générale Securities Services], for a specialist provider to monitor the collateral and provide full support to investors on the collateral process.” Heather Dale, Institutions Focus on Counterparty Risk, Fin. TiMES (London), Oct. 17, 2010, http://www.ft.com/ cms/s/0/7853d582-d877-11df-8e05-00144feabdc0.html\#axzz1EHxX6CSV.

52. OfFice of the Comptroller of the CurRency, OCC's Quarterly Report on BANK TRADING AND DERIVATIVES ACTIVITIES (2009), available at http://www.occ.gov/ topics/capital-markets/financial-markets/trading/derivatives/dq209.pdf. 
an unsecured out-of-the-money trade with $B$, $A$ 's failure does not allow you to net what $A$ owes you against what you owe $B$. You will collect only in part from $A$, but must pay $B$ in full. But if you had both trades with $B$, you could net the one you are obligated to pay on with the one you are ahead on, and thereby do better.) Setoff thereby encourages centralized, too-big-to-fail finance.

\section{By substituting into stronger financing structures}

Raising the expected private costs to the strong counterparties will press them to substitute away from risky instruments to more stable ones. Some substitution would be done at the stronger counterparties' insistence. Some could come via government prudential regulation, which the counterparties would be incentivized to support. And some substitution would come from the weaker party's own incentive to strengthen itself to garner more business so that its stronger counterparties would lower their charges. The next Subparts outline in greater detail these mechanisms and incentives.

\section{By moving from overnight repos to longer-term financing}

Before it failed, a quarter of Bear's assets came from repurchase agreements that were regularly rolled over until Bear got into trouble. ${ }^{53}$ Lehman was similarly financed. These overnight sale and repurchase contracts were effectively loans, with the difference between the repurchase price and the sale price as the interest rate.

Because the Code's priorities made these repos safer for Bear's counterparties, the Code enabled Bear to substitute short-term hot money for safer longerterm financing. A primary attraction for Bear's overnight lenders was that the loans were less risky because they were favored financially by the Code's superpriorities, enabling those lenders to charge Bear a bit less than otherwise. Other parties - in the end, the United States of America-accordingly took more risk.

One could conceptualize Bear's financing as a long-term, floating interest rate borrowing for one-quarter of its capital structure, with its lenders able to declare a default, accelerate their loans, and demand repayment on any day. Normally, a creditor accelerating such a loan cannot obtain immediate access to its collateral: the debtor files for Chapter 11 and the creditor, unlike the derivatives and repos counterparties, is enjoined from immediately liquidating the collateral. Eventually the secured creditor is repaid, but the prospect of delay can make creditors wary of dealing with potential bankrupts. ${ }^{54}$

53. See Bear Stearns Form 10-Q, supra note 4, at 5.

54. Because time is money, if the interest rate paid for the delay is not the market rate, the ordinary secured creditor is hurt. The Code requires that the court adequately protect the secured creditor, but what courts consider adequate, financial markets can consider inadequate.

Bear is said to have used collateral of decreasing quality over time, starting with treasury securities and trading down to mortgage-backed securities, such as those famous from subprime lending. When the lower-quality securities were recognized as such, Bear's counterparties asked for higher-quality collateral, which Bear could only provide for a time. 
If Congress raised counterparty risk for repos back up to the strong but incomplete secured creditor levels, then counterparties to a future Bear would have more reason than Bear's actual counterparties had in 2007 to want a stable counterparty. And firms like Bear would have more reason to keep themselves stable, because they could not so easily lower their cost of capital by using the overnight repo Code priorities. They might prefer to lower capital costs by having more equity and a more stable base of liabilities. A more stable base of liabilities would have more longer-term debt and less overnight hot money. Such shifts would make future financial failures less likely and, by making some key financial institutions more stable, also steady the financial system.

Some substitution will be simple. If the strong counterparty bears more risk in the derivatives or repo transaction, it will charge more. As it charges more, it will sell less.

\section{By setting better margin coverage earlier}

Repo and derivatives counterparties are exempted from normal preference and fraudulent conveyance restrictions on eve-of-bankruptcy creditor collateral calls and repayment pressures. As such, sophisticated, aggressive creditors could decide that they can set the early collateral margins low, without much of a cushion, so as to capture the business. If trouble hits later, they know they can make strong collateral calls that are exempt from normal bankruptcy risk. They can capture more business by keeping the margin haircut low, and-our issue here- they do not face bankruptcy impediments from following this path. ${ }^{55}$

\section{By discouraging knife's-edge, systemically dangerous financing}

We can generalize. The Code's superpriorities made the financial system less stable by subsidizing riskier borrower and lender behavior. With the repos golden under the Code, Bear and its lenders had reason to use them. With derivatives players knowing that they enjoyed superpriority, they could pay less attention to one major cost of trading-the risk that their counterparty could fail and default on its obligations. By minimizing counterparty risk, the Code could well have magnetized this kind of financing, pulling financing away from systemically better financing methods toward knife's-edge, overnight repos.

Bear's history is consistent. In 1989, 6\% of Bear's capital structure was in Code-protected repos; in 1994, 11\%; and, in 2008, 18\%. ${ }^{56}$ During that period, the Code's benefits to derivatives and repos expanded greatly.

55. A good way to handle the inevitable valuation problems for eve-of-bankruptcy collateral enhancements in the repo and derivatives markets is to analogize to inventory financing, which faces similar problems. The solution is to ignore changes in inventory levels in the ninety days prior to bankruptcy and to just assess whether the creditor was favored by an overall increase in inventory collateral over that period. See 11 U.S.C. § 547(c)(5) (2006); Thomas H. Jackson \& David A. Skeel, Jr., Bankruptcy, Banks, and Non-Bank Financial Institutions (Feb. 8, 2010) (unpublished manuscript) (on file with author).

56. See Bear Stearns Form 10-Q, supra note 4, at 5; The Bear Stearns Cos., Annual Report (Form 10-K), at 181 (Sept. 28, 1994); The BeAR StEARns Cos., 1989 Summary ANNUAL REPORT 21 (1989). The numbers are net numbers, subtracting Bear's repo assets from its repo liabilities. 


\section{Runs and Contagion}

Proponents of priority pointed to contagion risk to justify to Congress their getting advantaged treatment: a failed firm that left its derivatives and repo counterparties unpaid would drag those otherwise healthy firms down too. Critics of that view have already shown that priority could also knock the weakbut-not-yet-dead firm out as superpriorities encourage strong counterparties to grab the weaker firm's assets quickly, inducing old-style bank runs.

New thinking needs to be brought to bear as well. We now understand more about information contagion and collateral-value collapses than was understood when the original payment priorities entered the Code. I show next how new concepts of information and collateral contagion interact with the Bankruptcy Code deleteriously.

\section{The analytic bidding to date}

Regulators justly feared when the Code safe harbors first appeared that one financial failure could induce another and, like dominoes, the financial system could collapse. This fear justified treating derivatives and repos favorably. Less well understood when the Code was built, but now understood in academic analysis, ${ }^{57}$ was that the derivatives exceptions also increase the incentive of the failing firm's derivatives counterparties to close out their positions, thereby inducing financial failure. Indeed, in 2008 the Code's superpriorities may well have pushed derivatives and repo creditors of failing financial firms to rush to cash in their claims and upgrade their collateral, which other creditors could not do. ${ }^{58}$

Just as banks with illiquid assets are vulnerable to massive, nearsimultaneous requests from depositors for cash, leveraged firms with illiquid assets are susceptible to runs. If creditors sense a weakened debtor, then strong, favored creditors have reason to rush the debtor to repay. By so pressuring the debtor, they may dismember a firm that was valuable intact or whose diminishing value could have been better preserved if restructured.

Bankruptcy preference and automatic stay rules can stymie such runs: a bankruptcy court can recall such repayments made to creditors in the ninety days before bankruptcy. This rule encourages the major financial creditors to

One macro impact must be mentioned. Wall Street firms increasingly used mortgagebacked securities to back up their prioritized repos, especially after the 2005 Code amendments explicitly allowed them to do so and obtain the superpriorities. See Hördahl \& King, supra note 23, at 37, 46. They were borrowing short term, often overnight, to finance what were, when one dug down deep enough, long-term, illiquid assets (housing and real estate). The Code thereby made it easier to borrow short term to invest long term, which is an unwise financial combination. When widespread, it makes the financial system riskier and potentially less liquid.

57. E.g., Franklin R. Edwards \& Edward R. Morrison, Derivatives and the Bankruptcy Code: Why the Special Treatment?, 22 YALE J. ON REG. 91, 101 (2005); Partnoy \& Skeel, supra note 46, at 1049; David A. Skeel, Jr., Bankruptcy Boundary Games, 4 BRoOK. J. CorP. FIN. \& CoM. L. 1, 10-11 (2010).

58. A similar bankruptcy problem arises when higher-ranking creditors seek immediate repayment in ways that can stop an otherwise viable firm from reorganizing. See THOMAS H. JACKSON, THE LOGIC AND LIMITS OF BANKRUPTCY LAW 7-19, 125 (1986). 
negotiate contractual standstill agreements, under which each major creditor agrees not to pursue its remedies against the firm, so that a peaceful solution can be negotiated.

Derivatives counterparties need not feel so encumbered under the Code because they are not restricted. The derivatives' safe harbors from both preference law and the automatic stay incentivize the failing firm's counterparties to start a run. ${ }^{59}$ If the failing firm is financially central, the safe harbors thereby raise systemic risk, as Franklin Edwards and Edward Morrison have shown. ${ }^{60}$

\section{AIG: collateral calls, runs, and private lenders' refusal to lend}

The priorities hastened AIG's failure. As AIG weakened, its counterparties demanded collateral from AIG, sapping it of liquidity. ${ }^{61}$ Chapter 11 's automatic stay usually bars such collateral grabs, or its preference rules impede them, by pulling the grabbed collateral back into the bankrupt's estate to benefit all creditors.

The Code's core preference recovery concept is designed to reduce runs such as AIG's. ${ }^{62}$ But the Code doesn't apply its preference concept for one key class-derivatives counterparties-recreating the bankruptcy run problem. By omitting the preference concept for favored counterparties, the Code impedes firms like AIG from raising new money to stabilize themselves, as potential new investors want to wait until the run is over to see if enough value is left in the firm.

True, given the low penalty on a preference violation - the preferred party has to return the preference, without more-preference law is not an impermeable barrier to runs. ${ }^{63}$ Financiers subject to ordinary preference law have little reason to shun receiving preferences. But their incentives to actively seek preferred status are muted, and their incentives to agree to standstill while a deal is negotiated are raised, because their collection activity has a real chance of coming to naught, as the preference could be called back in the resulting bankruptcy. They are better incentivized to have a strong credit structure early on, because they lack the slack of being able to grab and keep eve-of-bankruptcy preferences. The derivatives counterparties' incentives are not so tempered: if they can get paid, they’ll keep their eve-of-bankruptcy payments. ${ }^{64}$

59. See Stephen J. Lubben, Repeal the Safe Harbors, 18 Am. BAnKR. Inst. L. ReV. 319 (2010); see also Duffie, supra note 27, at 68-69; Stephen J. Lubben, Derivatives and Bankruptcy: The Flawed Case for Special Treatment, 12 U. PA. J. Bus. L. 61 (2009).

60. Edwards \& Morrison, supra note 57, at 101; see also Partnoy \& Skeel, supra note 46 , at 1049.

61. See Stulz, supra note 9, at 64.

62. See JACKSON, supra note 58, at 125.

63. See Barry E. Adler, A Re-Examination of Near-Bankruptcy Investment Incentives, 62 U. CHI. L. REV. 575, 576 (1995).

64. And for traditional lenders, actively seeking preferential payment can shade into conduct that induces courts to equitably subordinate not just the preferred payment, but the entire loan. See In re Am. Lumber Co., 7 B.R. 519 (Bankr. D. Minn. 1979). Presumably derivatives players who position themselves to get the Code's benefits will not be subordinated for doing so. See In re Clark Pipe \& Supply Co., 893 F.2d 693 (5th Cir. 1990); In re W.T. Grant Co., 699 F.2d 599, 610 (2d Cir. 1983). 


\section{Credit contagion}

Proponents of payment priorities via the safe harbors brought forward contagion potential as a prime rationale. In this view, solvent counterparties become unable to extract their frozen collateral from a failing firm and then they also fail, which in turn brings down their own counterparties. This fear of contagion justified the Code's derivatives priorities. ${ }^{65}$ The Federal Reserve, which itself directly deals in repos when implementing monetary policy and could be inconvenienced if unprotected by the superpriorities, pressed the contagion argument on Congress. It did so despite the fact that the Treasury Department had rejected the contagion rationale ${ }^{66}$ for market-discipline reasons that I see as correct and, in 1983, prescient:

[P]arties [to repurchase agreements] do not merit better treatment under the Bankruptcy Code than any other party making a secured loan.... [T] ception of increased risk in the [repo] market is healthy, because it forces more responsibility in [repo] transactions by causing lenders to securities dealers to evaluate the financial condition of their borrowers, as creditors must ... in every other type of secured lending transaction. There is absolutely no likelihood of a government securities market breakdown from the effect of this discipline, as some have suggested, but rather an improvement in practices which will tend to prevent debacles....

... [W] [at Treasury] do not support legislation to exempt [repos] from the judicial stay provided for by the Bankruptcy Code. ${ }^{67}$

Properly analyzed, superpriorities in a financial crisis could either stifle contagion or spread it. ${ }^{68}$ They spread it by allowing counterparties to drain the already-weak firm of cash, which flows into the bankruptcy-favored counterparty. Which effect is more important is conceptually indeterminate, making contagion a poor theoretical rationale for superpriority.

\section{Information contagion}

Payment-priority backers focused on credit contagion: a failing firm first brings down its counterparty and then a row of financial dominoes follow. But

65. See H.R. REP. No. 109-31, pt. 1, at 20 (2005), reprinted in 2005 U.S.C.C.A.N. 88, 105 ("These provisions are intended to reduce 'systemic risk' in the banking system and financial marketplace.”); 128 Cong. REc. 15,981 (1982) (statement of Sen. Dole) (“It is essential that stockbrokers ... be protected from the issuance of a court ... order which would stay the prompt litigation of an insolvent's positions, because . . . the insolvency of one party could trigger a chain reaction of insolvencies ....”). Fear of contagion also motivated Congress to expand the safe harbors. See H.R. REP. No. 97-420, at 1 (1982), reprinted in 1982 U.S.C.C.A.N. 583, 583; 135 Cong. REC. S1414-15 (daily ed. Feb. 9, 1989) (statement of Sen. DeConcini); Philippe Jorion \& Gaiyan Zhang, Credit Contagion from Counterparty Risk, 64 J. Fin. 2053 (2009).

66. Compare Letter from Paul A. Volcker, Chairman, Bd. of Governors of the Fed. Reserve Sys., to Senator Robert J. Dole, Chairman, Subcomm. on Courts, Comm. on the Judiciary (Sept. 29, 1982) (on file with author) (asserting that the automatic stay on repos would undermine systemic liquidity), with Letter from Roger W. Mehle, Assistant Sec'y of Domestic Fin., Dep’t of the Treasury, to Senator Robert J. Dole (Mar. 16, 1983), available at http://www.sechistorical.org/collection/papers/1980/1982_0929_VolckerDoleT.pdf (stating to Congress that an automatic stay on repos posed no such threat).

67. Letter from Roger W. Mehle to Robert J. Dole, supra note 66.

68. See Edwards \& Morrison, supra note 57, at 94; Squire, supra note 47, at 1200. 
that Code thinking fails to reflect fear of information contagion. This absence is a mistake, and even the eve-of-bankruptcy considerations for superpriority need to be updated and rethought. For information contagion, the Code's impact is negative.

Consider a setting where creditors are poorly informed about their counterparties' financial health, because they, like many repo and derivatives players, rely more on collateral than on counterparty financial health. Because the Code's superpriorities give them immediate access to the collateral, they assess their counterparty's overall health less and their collateral value more. So, posit that an unexpected economic shock tells them that their collateral is worth much less than they had originally thought, such as the sudden revaluation of the subprime mortgage market, which did occur and made holders of repos backed by subprime mortgages revalue their contracts. Surprised, they suddenly call for better collateral and, when the debtor cannot post enough good collateral, they must rely on counterparty financial quality more than they previously had expected. But they are poorly informed about counterparty overall financial quality, because, until the shock, the Code gave them less reason to pay attention to it.

So when Bear, Lehman, and AIG failed, and the market repegged subprime mortgage collateral downward, creditors reevaluated their prior beliefs about the collateral they held from others and about their other counterparties' solvency. If they then had a deeper stock of direct information about their counterparties' overall strength, they might not have systematically repegged downward the quality of all counterparties. But the Code's superpriorities gave them little incentive to acquire much counterparty-specific information in the ordinary course of business. They faced an informational black hole, toward which they wished not to draw any closer. Hence, they stopped lending until they could acquire better information about their counterparties. This suddenly made their counterparties more illiquid. ${ }^{69}$

This result is a panic, with lending markets freezing up. "A panic [occurs when] information-insensitive debt [suddenly] becomes information sensitive. It is a switch because it becomes profitable to produce private information about the debt, ${ }^{70}$ or to produce more information about the debtor. That description resembles American financial markets in September 2008. If the players had previously better assessed counterparty risk, they would not have been left as clueless about counterparty quality. Failures such as those of Bear, Lehman, or AIG would not necessarily have made the entire financial market resemble an informational black hole, because creditors would have had glimmers of understanding of the color, depth, and shape of the other financial players' health.

69. See Gary B. Gorton, Slapped by the Invisible Hand 16-17, 48-49 (2010). For more on information contagion, see FrankLin ALLEN \& Douglas Gale, Understanding FinANCIAL Crises 260-95 (2007); Franklin Allen \& Douglas Gale, Financial Contagion, 108 J. POL. ECON. 1 (2000); Brunnermeier, supra note 24; and Douglas W. Diamond \& Raghuram G. Rajan, Liquidity Risk, Liquidity Creation, and Financial Fragility: A Theory of Banking, 109 J. POL. ECON. 287 (2001).

70. GorTON, supra note 69, at 51. 


\section{Collateral contagion}

The superpriorities facilitate a strong counterparty demanding better eveof-bankruptcy collateral from a weakened derivatives or repo counterparty. When many counterparties seek better collateral simultaneously, liquidate already-posted collateral, and thereby also induce their then-debtors to liquidate assets (to make the demanded collateral posts), the potential for a financial freeze-up is not small. The crisis of 2008 and 2009 partly stemmed from such a simultaneous effort across financial markets to sell collateral and debtor assets. $^{71}$

We thus now have reason to step beyond prior analyses that astutely indicated that the Code cannot arrest credit contagion. ${ }^{72}$ Worse than being unable to arrest credit contagion, the Code here can exacerbate information and collateral-value contagion. And in broad outline, the financial crisis suggests that it did both.

I have thus far emphasized the priorities' systemic weakening of financial structures over the long term by undermining market discipline at the time of contracting. But even at the time of a financial crisis, the old anticontagion raison d'être for superpriority is weak. Not only might superpriority exacerbate runs, as has been shown before, but it can exacerbate information contagion and collateral contagion, both of which were in play in the recent financial crisis.

\section{Why CONTRACT CANNOT SOLVE COUNTERPARTY RISK}

To summarize thus far: When one creditor's risks in an enterprise decline, another's rise. Once that other party understands it bears more risk, it should react by raising its interest rate, by seeking to reduce the risk it faces, or by improving its contract terms. The risk transfer structure of the derivatives and repo priorities has not yet been examined in this vital dimension. But perceiving now that the derivatives counterparties' lowered risk lowers their market-

71. See Gary B. Gorton \& Andrew Metrick, Securitized Banking and the Run on Repo (Yale Int'l Ctr. for Fin. Working Paper No. 09-14, 2010), available at http://www.ssrn.com/ abstract=1440752; Antoine Martin, David Skeie \& Ernst-Ludwig von Thadden, Repo Runs (Eur. Banking Ctr., Discussion Paper No. 2010-13S, 2010), available at http://arno.uvt.nl/show.cgi?fid=103635; cf. Samuel G. Hanson, Anil K. Kashyap \& Jeremy C. Stein, A Macroprudential Approach to Financial Regulation, 25 J. Econ. PersP. 3, 6 (2011) ("[W]hen Bank A takes on more [short-term] debt, it does not account for the fact that by doing so, it degrades the collateral value of any assets it holds in common with another Bank B-since in a crisis state of the world, A's fire-selling of its assets lowers the liquidation value that B can realize for these same assets.”).

The Dodd-Frank rules do better than bankruptcy in reducing collateral contagion. They do allow a brief stay, of one business day. That will not reduce collateral contagion much in itself. But during that time, the banking authorities can transfer the failed firm's derivatives book elsewhere, thereby reducing rapid collateral liquidation.

72. See Edwards \& Morrison, supra note 57, at 94; Squire, supra note 47, at 1200. 
discipline incentives is not enough, because it also raises other parties' risk and, hence, raises their market-discipline incentives.

However, a large slice of the default risk moves to parties that cannot, or will not, react contractually. Some are poorly positioned and too weakly informed to monitor the debtor's overall riskiness in general and its derivatives portfolio in particular. ${ }^{73}$ The new risk bearers are initially insurance policyholders, bank depositors, ordinary commercial paper buyers, and similar players who are often not well informed about the derivatives market. (To be sure here, the commercial paper and repo markets overlap. And the commercial paper players ought to have learned from the financial crisis what risks they bear due to others having superpriorities.) This shift of risk applies regardless of where the firm's risks come from; ${ }^{74}$ even if the increase in risk is coming from, say, the firm's core operations, the derivatives and repo exceptions put more of that risk on the shoulders of the firm's other creditors.

Modigliani and Miller demonstrated that varying a firm's capital structure does not in itself reduce total risk, as that risk emanates from the firm's operations. ${ }^{75}$ If one financier reduces the risk it bears, another financier picks up that risk. Absent an explanation as to how and why manipulating capital structure affects the firm's underlying operations and cash flows, risk is neither created nor destroyed, but can be shifted from one financier to another. Alan Schwartz, applying such thinking to secured credit, showed how secured credit reduces the risk borne by the secured creditor, but that risk moves to others who can price the risk unless they are tort claimants and similarly weak creditors. ${ }^{76} \mathrm{Lu}$ cian Bebchuk and Jesse Fried showed with precision how the risk can be inefficiently moved onto the shoulders of nonadjusting contract creditors. ${ }^{77}$

The second and larger reason why contractual reaction fails for superpriority risk-shifting is that the creditor eventually bearing the bulk of the transferred risk is the United States as guarantor of too-big-to-fail firms. The United States cannot react contractually in any grounded sense of contract. Instead, it can react by changing the rules of the game to account for its weak monitoring po-

73. See supra Part II.A.2-4.

74. While the conventional wisdom was that credit derivatives were central in bringing down AIG and others, some analysts show the centrality of the riskiness of AIG's core portfolio. See Squire, supra note 47, at 1183-87, 1203-04; cf. Viral V. Acharya et al., Manufacturing Tail Risk: A Perspective on the Financial Crisis of 2007-2009, 4 FounD. \& TRENDS FIN. 247 (2009) (describing excessive risk taking in large financial institutions). This view would extend the monitoring story: superpriorities reduced the incentives to monitor counterparty risk, with that counterparty risk emanating from both the immediate derivatives trades and from the firm's overall portfolio.

75. Modigliani \& Miller, supra note 42.

76. Alan Schwartz, Security Interests and Bankruptcy Priorities: A Review of Current Theories, 10 J. LEgAL STUD. 1, 1, 3, 7-8, 11 n.28 (1981). Schwartz indicates that a normative solution to the tort risk transfer mismatch is to make the tort claimants prior in payment to the previously benefited creditors. The analogue for derivatives and repos would be to make the United States senior in all settings.

77. See Lucian Ayre Bebchuk \& Jesse M. Fried, The Uneasy Case for the Priority of Secured Claims in Bankruptcy, 105 YALE L.J. 857 (1996).

On monitoring incentives and disincentives in general, compare Richard Squire, The Case for Symmetry in Creditors' Rights, 118 YALE L.J. 806, 818-19 (2009), with Saul Levmore, Monitors and Freeriders in Commercial and Corporate Settings, 92 YALE L.J. 49, 56 (1982). 
sition. For the United States, changing the Code's priority structure is how it would react quasi-contractually.

\section{A. Contractual Reaction and Its Limits}

\section{Financial covenants as partial solution}

Once burnt, twice shy. Ordinary creditors of financial firms in the future could take the debtor's derivatives exposure into account. A simple way to do so would be to limit the total derivatives exposure by an appropriate formula embedded in the creditors' loan agreements. This is common in other financial contracting: the lender lends, but requires that the debtor maintain a debt-toequity ratio of no more than, say, two dollars of debt for every dollar of equity. ${ }^{78}$ Derivatives could be folded into these kinds of financial contract covenants.

But derivatives counterparties can also react and, one expects, will do so. Some derivatives and repo counterparties did well due to their bankruptcy benefits, but others did not anticipate the financial crisis and, hence, did not take full advantage of the privileges that the Code offers them. Lehman's failure caught many derivatives counterparties short on collateral. In the next financial crisis, more counterparties will be prepared and, if the Code still permits them to do so, will demand collateral sooner, make sure that they can set off advantageously, and demand repayments more quickly that would otherwise be voidable transfers absent the exemptions. Postcrisis derivatives markets have already become more conscious of the import of managing collateral over managing counterparty risk. ${ }^{79}$ Contractual reaction may be an arms race going forward, for both the detrimentally affected creditors and the advantaged derivatives players. ${ }^{80}$

78. See Am. BAR Found., Commentaries on IndENTUREs 368-400 (1971).

79. See Chris Flood, Demand Rises for Collateral Solutions, FIN. TIMEs (London), May 30, 2010, http://www.ft.com/cms/s/0/57ca84ee-6a83-11df-b282-00144feab49a.html\# axzz1DmcmVSVD ("Rapid growth in the use of derivatives has been matched by a 'significant increase' in the demand for collateral management solutions, says Robert Coates of Viteos Fund Services. But the extreme volatility of asset prices during the financial crisis and heightened concerns about counterparty risk means collateral management has become an operationally intensive task ....”).

80. Could disfavored counterparties grab collateral earlier and thereby put themselves outside the bankruptcy preference recovery period? Not really. While Goldman, if lacking a safe harbor, might try to grab collateral ninety-one days before it initially expects a bankruptcy, $c f$. supra text accompanying notes 15-19, it cannot assuredly keep it. If the debtor filed more quickly, or were forced to file, Goldman's prebankruptcy take would be recoverable for the benefit of the bankrupt's other creditors. The early seizing of collateral is typically a public event, warning other creditors, who can demand repayment or force an early bankruptcy. This turns the seizure of collateral into day seven before the debtor's bankruptcy instead of day ninety-one. Goldman (if it lost its favored status) would be advised that creditors would react thus to early seizure of collateral, and so would have less reason to seize an insolvent counterparty's collateral and more reason to seek a collective remedy among creditors. See JACKSON, supra note 58, at 7-19, 122-50. If the preference rules induce the creditor to act early when the debtor is solvent (when everyone can then be paid), they induce an efficient early restructuring before the debtor deteriorates. See George G. Triantis \& Ronald J. Daniels, The Role of Debt in Interactive Corporate Governance, 83 CALIF. L. REV. 1073 (1995). Superpriorities undermine this beneficial impact. 
2. The necessary incompleteness of contract: the United States as de facto guarantor

Large financial institutions have a very large, passive creditor that does not act like an aggressive financial creditor with bond indenture covenants to enforce. The United States is a de facto creditor, as it pays up to rescue guaranteed and too-big-to-fail financial institutions. Even if private parties adjusted to their borrowers' derivatives and repo exposures, the derivatives market's prime creditor - the U.S. Treasury - does not and cannot move nimbly in this dimension. Its equivalent to contractual adjustment for the fire next time is regulatory adjustment now.

This is not a small point: private contractual reaction to the superpriorities is likely, now that financial players know the value of the priorities, but, because de facto the biggest creditor is the United States, contractual reaction will be unable to solve the major ex ante systemic problems. The United States as de facto creditor can only react by changing the regulatory framework, not by writing another clause into its bond indenture, because it has none. It is exposed and its conceptual equivalent to a bond indenture here is the panoply of financial regulation, including the Bankruptcy Code, which now largely, although indirectly, disfavors the United States. ${ }^{81}$

\section{B. The Regulatory Reaction Needed}

The most sensible bankruptcy reform for the United States, as de facto guarantor, is to cut back most superpriorities.

\section{Reshaping the Code's safe harbors}

The derivatives parties' ability to seize collateral should largely be folded into the secured creditors' strong but not all-encompassing power to do so. Strong counterparties would again be subject to ordinary preference and fraudulent conveyance law. The parties could continue to net or recoup obligations due to the bankrupt with those due from it, but not as automatically and only if the two are economically a single transaction.

This does not mean that derivatives players would be thrown cold and naked into the street, unpaid. As long as the debtor is solvent, its creditors would be paid in full. That will better motivate the derivatives players to deal with strong, solvent debtors who remain solvent, but not with weak ones that may well become wards of the state. This is the core of the ex ante analytic perspective I bring to bear on the derivatives and repo problem.

Second, some plain vanilla baseline derivatives transactions are not preferences or fraudulent conveyances. The typical derivatives transaction has a party place initial margin with a strong counterparty. As the market moves in one or the other's favor, the losing party posts variation margin. These ordi-

81. For banks-AIG, Bear, and Lehman were not banks-FDIC resolution can treat failed commercial banks' derivatives counterparties roughly as favorably as the Code does. See Michael H. Krimminger, Adjusting the Rules: What Bankruptcy Reform Will Mean for Financial Market Contracts, FDIC (Oct. 11, 2005), http://fdic.gov/bank/analytical/fyi/2005/ 101105fyi.html. 
nary-course posts correspond to actual, newly arising debts and do not present conceptual problems as either preference or fraudulent conveyances. ${ }^{82}$

The de facto priority problem is in how much further the Code goes. During the financial crisis, strong parties demanded more margin when they saw a weak counterparty. AIG originally had a AAA credit rating, without collateralposting obligations. But the counterparties' contracts allowed them to demand collateral if AIG's credit rating was downgraded, which they did. This is the kind of collateral demand from a newly weak firm that the Code usually seeks to deter via the preference recovery rules, § 547 and $\S 550$. These transfers were conceptually preferential, but were safe from attack due to the superpriorities. Such eve-of-bankruptcy collateral calls in derivatives and repo markets should be reclassified as nonexempt, voidable preferences.

\section{Justified exceptions for the derivatives and repo markets}

While I analyze the overbroad nature of the priorities, not every payment priority lacks merit. I next point to three justified exceptions for derivatives and repos.

Consider the netting rules. The Code allows a derivatives player to net its obligations to the bankrupt with obligations from the bankrupt. Netting can be valuable for the nonbankrupt counterparty even if the obligation to the bankrupt is identical in size to the obligation from the bankrupt. If the counterparty owes the bankrupt $\$ 100$ million on one contract and is owed $\$ 100$ million on another, the typical result, without netting, is that it must write a check to the bankrupt for $\$ 100$ million, but it receives only a fractional return from the insolvent bankrupt. If the return to the bankrupt's creditors is only ten cents on the dollar, a no-netting scenario yields the counterparty a $\$ 90$ million loss. Netting gets it that extra $\$ 90$ million. As between it and the debtor, this result is fair. But as between the counterparty and the debtor's other creditors it may not be. If the bankrupt is a bailed out, financially central institution, the United States bears that $\$ 90$ million loss. The local attractiveness of derivatives netting among financially central firms is partly due to this risk transfer away from the firm and its creditors, to the United States.

The derivatives industry had reason to want Congress to clarify that typical, basic swap contracts were integrated economically and should be treated as a single unit in bankruptcy. The derivatives players' legitimate netting goal is to net two sides of an economically integrated single contract. Here's why: A swap arrangement exchanges risk. One side promises, say, to pay LIBOR, the London Interbank Offered Rate, a benchmark interest rate that floats according to market conditions. The other side promises to pay a fixed rate of, say, $5 \%$. (One side shuns the risks of interest rate changes, while the other side can bear them. So they trade.) An overly broad anti-netting rule could force the counterparty to pay the full 5\%, but only allow the counterparty to collect a fraction of the floating rate obligation from the insolvent debtor. But this trade was economically a single contract, not two discrete deals. They should be netted and, even absent a Code safe harbor, ought to have been seen to be a single contract.

82. See 11 U.S.C. § 546(e) (2006). 
But the Code again goes much further. It allows the counterparty to net unrelated trades, as long as they can be called derivatives or repurchase agreements. And its scope has been so broad as to allow a party to net a winning position with the bankrupt against a losing contract (which the bankrupt would only pay fractionally) that the counterparty acquires after the debtor fails and is rolling toward bankruptcy. Such transactions are conceptually voidable preferences.

That is, strong counterparties have been able to net strategically, by acquiring a flimsy obligation from the debtor and getting it de facto paid dollar for dollar by matching it with a nettable obligation to the debtor. Goldman and others did this with the failing Bear Stearns. Said one trader: "My shareholders ... said, 'You're ... crazy. Why are you guys taking [such a] credit risk without making money?' ... [But] it just nets you down and offsets, because you've made your money on the other side of the trade." 83

Consider termination rights. Ordinarily the bankrupt debtor chooses whether to terminate or assume its prebankruptcy contracts. If it assumes, it is fully obligated to perform. If it terminates, it is liable to its counterparty. But the damages are rarely paid in full; they are paid pro rata in discounted "bankruptcy dollars," with the contracting party sharing the bankrupt estate with all of the bankrupt's other creditors.

The Code is generous, possibly overly so, to the bankrupt debtor in giving it so broad an option. But this rule reversal for derivatives players alone requires justification. That justification could come from the chaotic consequence of having unclear, open-ended obligations for months after a Chapter 11 filing, as the bankrupt decides whether to assume or reject, paralyzing financial counterparties. But industrial counterparties can also be severely damaged if the bankrupt takes its time deciding whether to assume or reject. Financial players have no monopoly here on inconvenience. Second, the Code could instead force the debtor to decide in short order whether to assume or reject. ${ }^{84}$ Third, a more neutral rule would terminate all contracts upon the filing of a bankruptcy, thereby disallowing either side from playing the market and cherry-picking to affirm profitable contracts while terminating losing ones. ${ }^{85}$

83. CoHAN, supra note 12 , at 30 . As before, this is fair when the priority rule only affects the two immediate players. But the risks keep moving and eventually reach the United States.

Cutting back setoff will not be transactionally easy. Parties can rewrite unrelated contracts into a single contract that blends otherwise unrelated bets into a single net amount due. To some extent, the standard master derivatives contract does this.

84. The debtor's option also affected commercial lease markets. To reduce the debtor's optionality impact on lessors, Congress required that the debtor decide whether to assume or reject within 120 days of the filing of the bankruptcy petition. See H.R. REP. No. 109-31, pt. 1, at 86 (2005), reprinted in 2005 U.S.C.C.A.N. 88, 153. The time frame could be tighter for financial contracts.

85. Thomas Jackson and David Skeel indicate that a properly drafted contract could readily reduce debtor cherry-picking under ordinary bankruptcy rules. Jackson \& Skeel, supra note 55, at 36-37. The derivatives lobby's characterization of the threat may have been overblown. 


\section{COUNTERARGUMENTS FROM COUNTERPARTIES}

Several strong and not-so-strong counterarguments to the analysis I have offered in this Article are relevant, but none is strong enough to reverse it.

First, counterparties rely on the weak firm being too big to fail, regulatory proponents would say, making derivatives counterparties' ranking in the Code's priority structure unimportant. Changing the Code will not change outcomes. Second, classic bankruptcy-based justifications for limiting creditors' collateral seizures do not apply to derivatives and repos, some would argue, because the underlying asset is not connected to the bankrupt's operation in the way that, say, the steel smelter is needed for the steel mill. Hence, the broad superpriorities are appropriate bankruptcy policy and should not be changed. Lastly, priority proponents would say that derivatives and repos are vital for the financial engineering needed to make today's financial system work. Without priority, the financial system and end users will suffer.

\section{A. Would Repeal Change Derivatives Market Incentives?}

Critics of repeal might argue that strong counterparties expect the government to bail out failed, weak counterparties. Accordingly, reducing the Code's priority favoritism will not affect the strong parties' expectations. They'll ignore counterparty risk regardless of the priority rules, because the government will always step in.

However, firms are unlikely to fully rely on a government bailout. Lehman failed in 2008 when the Treasury let it go under; Drexel failed two decades earlier. Governments say they will not bail out creditors next time. Although they often do not carry out their threats, there is genuine uncertainty about what the governments will do, because their actual strategy is mixed and hard to predict. ${ }^{86}$ Second, a financial firm may be failing but not be too big to fail. If repeal affects behavior and induces strong counterparties to diversify their counterparties further, the increasing number of stronger counterparties will make each one less vital systemically.

Financial players' actions indicate both that they are uncertain about what the United States will do and that they value superpriority. These players lobbied hard to get derivatives priorities extended in 1982, 1984, 1994, 2005, and 2006, and to keep them in 2010. If they did not care about priority because they fully expected government bailouts, then they would not have lobbied for the superpriorities. If the probability of a government bailout is positive but uncertain (i.e., not $100 \%$ ) the analysis here applies.

The derivatives and repo markets are said to be shocked when their priorities are questioned. ${ }^{87}$ The repo market did grow more quickly as payments

86. See Charles P. Kindleberger \& Robert Z. Aliber, Manias, Panics, And Crashes: A History of FinANCIAL CRISEs 20 (5th ed. 2005).

87. See Jeanne L. Schroeder, A Repo Opera: How Criimi Mae Got Repos Backwards, 76 AM. BANKR. L.J. 565, 567-68 (2002) (“[Prior to the 2005 amendments, a court's suggestion that repos might be recharacterized as secured loans] sent shockwaves through the financial industry ... [because it placed] [b]illions of dollars in notional amounts of outstanding repos ... in danger of being labeled as security interests ....”); Simkovic, supra note 13 , at 282. 
priorities were expanded, as Figure 2 illustrates, although it's hard from that alone to conjecture the extent to which that would have happened without the priorities. Still, from 1981 until the financial crisis, the repo market grew twice as fast as did overall financial markets. ${ }^{88}$

FIGURE 2

Growth in the Market for Repurchase Agreements and for All Financial Sector Debt, $1981-2009^{89}$

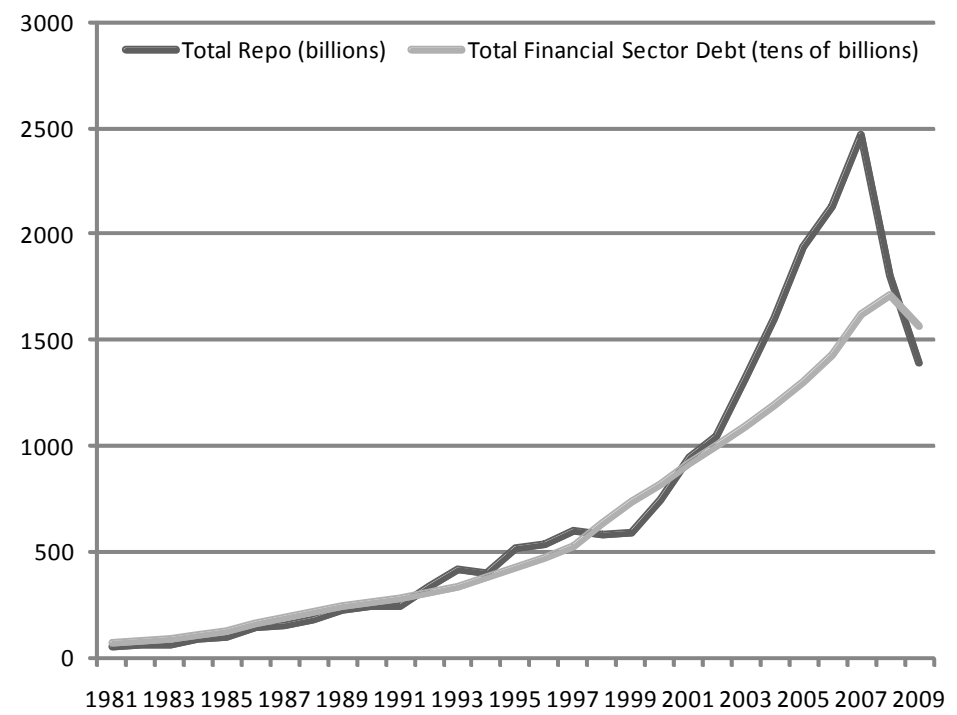

Second, consider the derivatives industry's reaction to postcrisis congressional and FDIC reform proposals that priority be limited to $90 \%$ of the relevant debt. Reactions included: "Wall Street dealers are facing their worst fear," ${ }^{90}$ and "Banks have warned that the provision ... could have a chilling

88. Total financial sector debt was twenty times larger at the end of 2006 than it was in 1981, the first year available for repo data. See BD. OF GOVERNORS OF THE FED. RESERVE SYs., supra note 7, at 9. But the repo market grew more, to more than fifty times its 1981 size. Much of the relatively greater growth was in the 2000-2007 period. Repo market information is from Statistical Supplement to the Federal Reserve Bulletin, BOARD GOVERNORS FED. RES. SYS., http://www.federalreserve.gov/pubs/supplement/default.htm (last updated Jan. 28, 2011) (data available in Table 1.43 of each month's bulletin); and U.S. Government Securities Dealers-Positions and Financing, FED. RES. ARChIVAL SYs. FOR ECON. RES., http://fraser.stlouisfed.org/publications/frb/page/31488 (last visited Feb. 17, 2011). A slowing of repo growth in the 1980s is consistent with the view that court decisions unfavorable to priority affected the market, but this is hardly dispositive.

89. Financial sector debt information is from BD. OF GOVERNORS OF THE FED. RESERVE SYS., supra note 7, at 9. Repo market information is from Statistical Supplement to the Federal Reserve Bulletin, supra note 88; and U.S. Government Securities Dealers-Positions and Financing, supra note 88.

90. Michael Mackenzie \& Helen Thomas, Repo Dealers Fear Legislation Will Drain Liquidity, FIN. TIMEs (London), Dec. 7, 2009, http://www.ft.com/cms/s/0/c26678c2-e35a -11de-8d36-00144feab49a.html\#axzz153BhFB1C. 
effect on the 'repo' market and thus on broader credit availability." 91 One financial player said: "The proposed legislation will certainly reduce leverage and liquidity in the repo market." 92 The chief executive of the Securities Industry and Financial Markets Association was more vociferous, saying the proposal "would negatively affect the efficient operations of the credit markets, increasing the cost of raising capital." ${ }^{93}$ A spokesman for the International Swaps and Derivatives Association, an arm of the large derivatives dealers, wrote that without "close-out netting, it is questionable whether over-the-counter derivatives - or repurchase agreements or clearing houses_-would be viable." 4 Leading academic defenders of the repo markets judge that without the bankruptcy priorities the market would shrivel. ${ }^{95}$

"One head of repo [operations] at a leading bank was blunter, calling the proposed legislation, 'nuclear' for the market." ${ }^{\text {"6 }}$ The proposal's congressional proponent, Brad Miller, indicated intuitions consistent with my thesis here. His proposal, he pointed out, would, if enacted, have "put[] pressure on anyone lending to a systemically significant firm to pay attention to what sort of shape the firm is in .... No one was paying attention to Lehman."97

The derivatives industry takes these priorities seriously and does not rely on an assured government bailout for protection.

A similar counterview might be that derivatives and repo players would not substitute away into stronger, longer-term financing. One cannot be sure, but anecdotal indications support substitution. First are the industry's own warnings of dire consequences, as above. If they say their market may collapse if the superpriorities are weakened, then weakening superpriorities should lead the players to do less derivatives and repo business than they do now. Second, the repo market's growth seemed to slow in the early 1980s, when a court decision $^{98}$ left uncertain whether repos were subject to the automatic stay. ${ }^{99}$ Third,

91. Tom Braithwaite \& Michael Mackenzie, Creditors to Foot Bill in U.S. Risk Regulation, Fin. Times (London), Dec. 2, 2009, http://www.ft.com/cms/s/0/558799be-df9c-11de -98ca-00144feab49a.html.

92. Id.

93. Id.; accord Cheyenne Hopkins, Creditors Fear New Resolution Process, АM. BANKER, Dec. 7, 2009, at 1.

94. David L. Mengle, Close-Out Netting and Risk Management in Over-the-Counter Derivatives 1 (June 1, 2010) (unpublished manuscript), available at http://www.ssrn.com/ abstract $=1619480$.

95. See Gary Gorton \& Andrew Metrick, Regulating the Shadow Banking System 3 (Oct. 18, 2010) (unpublished manuscript), available at http://www.ssrn.com/abstract= 1676947 (“[T]he bankruptcy 'safe harbor’ for repo has been a crucial feature in the growth of shadow banking ....”).

96. Mackenzie \& Thomas, supra note 90.

97. Braithwaite \& Mackenzie, supra note 91 (omission in original). Ex post haircuts are not a good way to strengthen market discipline. 1982).

98. In re Lombard-Wall Inc. v. Bankers Trust Co., 23 B.R. 165 (Bankr. S.D.N.Y.

99. See Kenneth D. Garbade, The Evolution of Repo Contracting Conventions in the 1980s, FRBNY ECON. PoL'y REV., May 2006, at 27, 35-37; Carolyn Sissoko, The Legal Foundations of Financial Collapse 5-6 (Oct. 6, 2009) (unpublished manuscript), available at 
the growth in asset-backed repo securities has been said to depend on the availability of the Code's superpriorities. ${ }^{100}$ Presumably denying the priorities would stifle or reverse their growth.

A related comment: It's tempting to imagine what would have happened if the superpriorities were not in place when AIG, Bear, and Lehman failed. One might mistakenly conclude that repealing the superpriorities would have no impact, because in 2007 and 2008, superpriorities or no superpriorities, the firms were doomed.

That, though, is not the right way to consider the situation, as the ex ante incentives-based analysis I am pressing here indicates. Instead, imagine the impact on the three failed firms' capital structures if the superpriorities had not been in place for years before their failure. Would Bear and Lehman have been so heavily financed with risky overnight repos? Would AIG's derivatives counterparties have put so many derivatives eggs in the AIG basket? Would they have tolerated AIG's risky portfolio overall? Would the derivatives and repo markets have been as large as they were? We need to imagine what the longterm ex ante adjustment would have been.

One would hardly say that bankruptcy priority alone generated the financial crisis or that fixing it is the silver bullet that will prevent future crises. Rather, it's an important problem and one that is underanalyzed, underappreciated in Congress, and readily remediable.

\section{B. The Unnecessary Asset?}

Classic justifications for the bankruptcy stay against creditors seizing security, against preferences that shred the firm, and similar limits on creditors are these: The firm is often worth more held together rather than shredded, so the Code's limits slow the shredding process down long enough for the judge and the parties to determine whether to reorganize the firm. The firm retains critical assets to maximize the total value of the bankrupt firm, and the affected creditor is compensated for its loss.

Is the collateral backing derivatives and repos that kind of vital asset?

Maybe not. The bankrupt steel firm cannot continue its business without the steel smelter, so bankruptcy bars creditors with a security interest in the smelter from seizing the smelter while the Chapter 11 process runs its course. The Code protects those creditors, assuring them that they will eventually get full value, although not immediately. ${ }^{101}$

But if the asset that the counterparty seeks to seize is not analogous to the illiquid, difficult-to-value, difficult-to-substitute-for smelter, superpriority advocates might assert there's no reason to stay such financial seizures. It's not a

http://www.ssrn.com/abstract=1525120. Of course, extracting a trend from one event, especially one corresponding to a weak economy, is an interpretive indication, not proof.

100. See Jennifer S. Taub, A Whiff of Repo 105, Baseline SCEnARIO (Mar. 16, 2010), http://www.baselinescenario.com/2010/03/16/a-whiff-of-repo-105 (former Fidelity legal official tying priority structure to repo market growth).

101. Creditors often conclude that they are not getting full financial value, but the theory is clear: keep the asset in the firm, reorganize, and then pay the affected creditor in full. 
critically interconnected factory that fits tightly and of necessity with the bankrupt's other operations. ${ }^{102}$ Cash is generic; a steel mill is not.

This argument is strong for an industrial firm. The cash-strapped firm could be made to show its longer-term survivability; if it's viable, it should be able to refinance itself in a good financial market with the new lender priorities that the Code allows. ${ }^{103}$ (If this were the main counterpoint here, more would need to be said.)

Although strong for an industrial firm, the unnecessary-asset view is weak for a financial firm, which needs the very liquidity that superpriorities damage. The failing financial firm's liquidity via its cash and near-cash assets can be as critical for its survival as the smelter is for the steel manufacturer. How far one should go here is open to debate, and allowing the bankrupt unimpeded access to cash collateral would be strong medicine. But if derivatives and repo counterparties seize enough value from the failing firm, the financial firm is sapped of liquidity. Dried out, it cannot operate. It dies. ${ }^{104}$

Another way to think of this defense of superpriority is that the automatic stay need not apply to assets unrelated to a debtor's operation if there's a wellfunctioning credit market. A new loan can substitute for cash but not for a customized, difficult-to-value smelter. But in the financial crisis we experienced in 2008, there was no functioning credit market, a situation that made financial firms' ability to retain liquid assets as potentially important to their survival as retaining unique operating assets is for the industrial firm. Thus the classic justification for the stay and for preference law extends to derivatives and repo contracts for the financial firm. (I add this view here for completeness. Which way one comes out on the issue is not critical: even if the financial asset is unnecessary to the financial firm's operations, we would need to trade off between releasing the unnecessary asset ex post with the need for better ex ante market discipline. The latter now seems more important than the former.)

Lastly, the liquidity-as-financial-firm-asset concept interacts with the bankruptcy stay and with runs in another dimension, as we saw above. Assets, typically financial assets, back derivatives and repos. When a counterparty can seize and sell the asset of a defaulting player, it can quickly exit its contract. When many counterparties seek to liquidate similar underlying assets at the same time, the potential for a financial gridlock increases. ${ }^{105}$ Consider Ben Bernanke's statement:

[S]hort-term repos had always been regarded as virtually risk-free instruments . . . . In March [2008], . . . repo markets [were] severely disrupted when investors believe[d] they might need to sell the underlying collateral in illiquid markets. Such forced asset sales can set up a particularly adverse dynamic, in

102. See Edwards \& Morrison, supra note 57, at 114.

103. See 11 U.S.C. § 364 (2006).

104. Cf. Mark Carey \& René M. Stulz, Introduction to The Risks of FinANCiAL Institutions 1, 6 (Mark Carey \& René M. Stulz eds., 2006) (“[R]isk management is uniquely important for financial institutions because, in contrast to firms in other industries, their liabilities are a source of wealth creation for their shareholders. For instance, a financial institution that writes long-dated derivatives would usually be shut out of the market if the credit rating of the vehicle it uses to write such derivatives fell below an A rating. ... . [A financial institution's] franchise value depends on the risk of its insolvency . ...”).

105. See sources cited supra note 71. 
which further substantial price declines fan investor concerns about counterparty credit risk, which then feed back in the form of intensifying funding pressures. ${ }^{106}$

The bankruptcy's automatic stay could dampen a financial crisis, because the stay would have reduced simultaneous asset grabs and asset sales.

\section{Financial Necessity: Are Derivatives and Repos Like Banking?}

Policymakers may, and the derivatives industry surely will, argue that the derivatives industry requires priority in order to work. Repurchase agreements and derivatives enhance liquidity and risk management, and liquidity and risk management are important for the economy. Just look at the depth of securities firms' financing via repos and the wide use of credit derivatives to control risk. If Congress denies them their Code-based advantages, it will damage the economy's financial arteries.

The problem is not that many derivatives and repos fail to provide real benefits. The problem is that there's no reason, on that assertion of importance alone, to favor derivatives and repos over other financial contracts. Restaurants need food deliveries to survive, and people need to eat food. Steel mills need iron, coal, and cobalt to make steel; the steel industry is economically important and hence priority for deliveries, their iron suppliers might say, is vital. Borrowers need capital; firms need labor. Firms need telecommunications. These are true statements about the economic importance of food, steel, iron, lending, working, and the telephone, but that vitality alone does not justify priority for food deliveries to restaurants and for iron deliveries to steel mills. They all deserve priority. But when the debtor lacks sufficient value to pay all its creditors, they cannot all have it. Each transaction needs to stand on its own. If repos and derivatives are privately valuable, people will pay for them. For now, we subsidize them.

Many economic and financial transactions are beneficial and some are essential. But saying so does not justify prioritizing and subsidizing one side or the other of the trading relationship over the counterparties' other creditors and trading partners, whose trades also benefit the economy.

Priority transfers risk to other players who also provide economic benefits. Those transfers and subsidies are hidden and, when widespread, pernicious.

Congress would need to be convinced that repos and derivatives provide some critical benefit with spillover effects. It's the extra benefit from positive spillovers that would justify jumping such financial contracts to the head of the bankruptcy queue. But to state their potential for spillover benefits is to state their costs: we may have overused these financial products, due to their favored bankruptcy status, thereby exacerbating a financial crisis and knife's-edge financing. From what we now know, spillovers are at least as likely to be negative as positive. In the absence of compelling evidence either way, policy

106. Ben S. Bernanke, Chairman, Fed. Reserve Bd., Remarks to the Risk Transfer Mechanisms and Financial Stability Workshop (May 29, 2008) (transcript available at http://www.federalreserve.gov/newsevents/speech/bernanke20080513.htm). 
should be neutral. Derivatives should be treated like other financial obligations. $^{107}$

Consider another financial necessity argument: Derivatives and repos have become so fundamental to American financial markets that they resemble the bank payments system in their foundational necessity. Just as check-clearing and savings activities should be safe and fully transparent so that depositors need not fear bank failure, for Wall Street to function in the twenty-first century, it needs repos, and both Main Street and Wall Street now need credit derivatives to manage risk. These instruments are vital for finance, this view would have it, and players using them need additional protection because they cannot be concerned with their counterparties' creditworthiness.

Two caveats, both substantial, militate here against such favoritism. First, the derivatives and repo markets are not widely populated by financially naïve retail bank depositors. Rather, the center consists of sophisticated financial players.

Second, if derivatives and repos resembled the payments system in needing protection and transparency due to their systemic importance, the proper regulatory reaction would not at all be ad hoc bankruptcy priorities. Rather, Congress would need to complete the regulatory and contractual loop by recognizing that the United States is that market's missing creditor and that the United States needs to complete its contingent, de facto contract status with a regulatory structure that approximates that which we use for deposit banking. There would be greater risk controls and regulation. The derivatives and repo players would be charged for the government guarantees. We now get the costs of favoring derivatives, but without the full panoply of benefits and controls. ${ }^{108}$

I am not arguing that derivatives and repos have systemic benefits at the level of bank deposits. But if this view is given weight in Congress, the appropriate reaction is a regulatory overlay that recognizes systemic value, regulates the resulting risk, and charges the derivatives market for the government support, not an ad hoc set of bankruptcy superpriorities.

\section{Preserving Priority}

Collateralized derivatives, special purpose vehicles, ${ }^{109}$ secured credit, and unsecured senior debt all lie on a spectrum of priority in bankruptcy. Several of the reasons to doubt the overall public economic value of derivatives' priorities apply to these other types of financing, albeit not the major reasons. We need

107. Solely focusing on the safe harbor's extra benefits to the derivatives and repo players is itself not logically entailed here. If serious systemic costs emanated from ordinary treatment of derivatives, and did so without offsetting benefits, then the logic of incentives and systemic risk would point us to considering cutting back ordinary treatment.

108. Cf. Morgan Ricks, Shadow Banking and Financial Regulation 1, 27 (Aug. 30, 2010) (unpublished manuscript), available at http://www.ssrn.com/paper=1571290.

109. A special purpose vehicle is a separately incorporated firm, structured to be difficult to enter Chapter 11 (hence, they're often called "bankruptcy remote"), into which a firm moves assets for the purpose of financing itself. 
not abandon the spectrum altogether, but we should examine the justifications for elevating derivatives and repos to the high end of that spectrum. Thus far, only derivatives priorities have made the United States a major de facto creditor and guarantor of the derivatives firms. And, thus far, only derivatives priorities have exacerbated a major financial crisis and economic downturn.

True, the affected financial players might react to repeal by constructing separate bankruptcy-remote vehicles. ${ }^{110}$ The new vehicles would be affiliated with the core financial institution, but allow their creditors to seize value from the separate entities if the core firm fails. Such bankruptcy-remote special purpose vehicles are widely used elsewhere. ${ }^{111}$ But removing the derivatives book from the core financial institution differs sharply from the usual bankruptcyremote issue of the debtor creating a firm with priority over its other creditors because the separate vehicle gets especially "good" assets. Removal pushes the derivatives book out from the systemically vital institution to a separate affiliate. By pushing it out, market players would be removing the derivatives risks from having a call on the financially sensitive bank's equity and, hence, from having a call on the government's guarantee. This is the public policy goal we should be seeking.

The financial industry has relied on the safe harbor priorities, convinced Congress to expand those priorities, and did not see fit to rely heavily on using such bankruptcy-remote affiliates for derivatives trading. If the safe harbor priorities were cut back, the industry, I hope, would substitute toward safer financing, and that could include well-capitalized bankruptcy-remote vehicles that do not put the core financial institution's capital at risk. Indeed, requiring affiliates to handle all derivatives trading was a regulatory proposal that the derivatives-trading banks vociferously opposed, ${ }^{112}$ presumably because counterparties want access to the government-guaranteed institution and the bank's capital to back up the obligations. Partial separation became part of the DoddFrank bill as passed. ${ }^{113}$

110. See Kenneth Ayotte \& Stav Gaon, Asset-Backed Securities: Costs and Benefits of “Bankruptcy Remoteness,” REV. FIn. STUD. (forthcoming) (manuscript at 1-2), available at http://rfs.oxfordjournals.org/content/early/2010/09/13/rfs.hhq059.full.

111. Again, bankruptcy-remote affiliates are companies that hold the target assets and are kept separate from the core company. Even if the core company goes bankrupt, the affiliate should not. It would thereby pay its debts outside of the core firm's bankruptcy.

112. See Wall Street Transparency \& Accountability Act of 2010, S. 3217, 111th Cong. (as reported by S. Comm. on Agric., Nutrition, \& Forestry, 2010), available at http://ag.senate.gov/site/legislation.html; Scott Patterson \& Robin Sidel, Finance-Bill Proposal Worries Banks, WALl ST. J., Apr. 27, 2010, at A4; Edward Wyatt, Veto Threat Raised over Derivatives, N.Y. TimEs, Apr. 17, 2010, at B1 ("The measure would . . r require banks and Wall Street firms to spin off much of their derivatives operations into a separate subsidiary .... Financial institutions will fight that provision vigorously.”).

113. A third and further analytic issue is the application of differing rules: the Federal Deposit Insurance Act applies to commercial banks, while the Code applies to investment banks. But the FDIC priority and safe harbor rules are analogous to the Code rules, as the derivatives industry sought and obtained parallel safe harbors in the Code and under banking regulation. Changes should occur in parallel fashion. 


\section{E. Transition}

Regulatory transition is a related issue. Although derivatives and repos do not merit regulatory subsidy, they are financially important in the markets that we have now, partly because the Code subsidizes them. Any transition should not be abrupt, so that markets can smoothly adjust.

Also, transition will not be easy politically. Incumbent groups benefit from the superpriorities, know what they are, and will oppose reform, a characteristic that often stymies change. ${ }^{114}$ It's unclear from where lobbying for change would come. Some explanation for the existing superpriorities must come from the lobbying power of the benefited financial institutions. The arguments against the superpriorities are substantial, but neither self-evident nor amenable to political and media sound bites, making interest group lobbying potential here strong.

Moreover, change is costly and the rules in place, even if unwise when enacted, will impose costs as well as benefits if changed. ${ }^{115}$ The day-to-day transactional world of finance relies today on using derivatives and repos in many settings and will seek to keep that world, either by resisting rule changes or by creating close substitutes if the rules change anyway. But if the close substitutes do not present systemic risk, they are better than the current arrangements, as I indicated in the prior Subpart.

\section{F. Extent}

The market-discipline disincentives warn us to be wary of the Code's superpriorities for derivatives and repos, and these priorities and safe harbors need to be limited. The Code's exceptions transfer risk from one of the financial firms' creditors to another, with those risks eventually ending up in the hands of the United States. The United States needs to react like a contractual creditor would, but, lacking a contract, it must use its regulatory tools, such as the Code.

But not all derivatives contracts involve systemically vital institutions that push risk onto the United States. One counterargument is that any rollback should not affect, say, industrial end users of derivatives. Rolling back the Code might be best implemented technically by across-the-board application, or by targeting a rollback to systemically vital financial firms but not ordinary financial and industrial firms; I offer here no justification as to where, or whether, to draw the line. If only for political expediency, industrial end users outside of the financial core may have to be exempt (i.e., with their counterparties retaining superpriority), although this tweak to cutback carries some politi-

114. See, e.g., Mark J. Roe, Chaos and Evolution in Law and Economics, 109 HaRv. L. Rev. 641, 652 (1996); Enrico Perotti \& Paolo Volpin, Lobbying on Entry (Eur. Fin. Ass'n 2004 Maastricht Meetings, Paper No. 2277, 2004), available at http://www.ssrn.com/ abstract $=558588$.

115. See Lucian Arye Bebchuk \& Mark J. Roe, A Theory of Path Dependence in Corporate Ownership and Governance, 52 STAN. L. REV. 127 (1999). 
cal risk that the financially central firms will use the end users as a wedge to defeat any rollback. ${ }^{116}$

\section{What The DodD-Frank FinANCIAL REForms Do AND FAIL to Do}

\section{A. Dodd-Frank: Nothing on Bankruptcy Superpriorities}

Congress recently passed a major financial overhaul, the Dodd-Frank Act. ${ }^{117}$ It did not change bankruptcy priorities. It does mandate that derivatives trading be pushed out from the insured institution via the so-called Volcker rule, which seeks to stymie banks' proprietary derivatives trading. ${ }^{118}$ Whether these provisions can be effectively implemented is yet to be seen.

Dodd-Frank provides for a nonbankruptcy liquidation mechanism for systemically important financial institutions. ${ }^{119}$ The FDIC can restructure the failed entity and move its assets and liabilities out from the failed entity. Because each creditor entitlement ties to the Bankruptcy Code, the Code is potentially still central formally. ${ }^{120}$ As importantly, Dodd-Frank contemplates a resolution procedure likely to put the derivatives players in about the same position as the Code puts them: there is an automatic stay of sorts in Dodd-Frank for financially central firms - but only for one business day. During that business day, the financial regulators are expected to arrange for the transfer from the failed institution of its entire derivatives book; they cannot cherry-pick among a counterparty's contracts with the debtor. That is, the stay allows the regulator to find a party that will pick up the derivatives book, which may well effectively cover the unsecured portion of the derivatives book. While the oneday Dodd-Frank stay is more onerous than the Code's lack of any stay, the expectation of the regulator making good on the unsecured portion of the failed firm's derivatives book is better. If the regulator fails to transfer the book in one business day, the automatic stay lifts.

\section{B. A Derivatives Exchange: Many Eggs, One Basket}

The major derivatives safety initiative in Dodd-Frank is to mandate a clearinghouse or exchange for many derivatives. ${ }^{121}$ The clearinghouse would promptly call for new collateral if the value of the derivative contract declines.

116. Cf. A Financial Reform Reprieve, WALL St. J., Mar. 12, 2010, at A18 (identifying companies such as Alcoa, Boeing, Caterpillar, Disney, and Procter \& Gamble that lobbied to be exempt from derivatives regulation).

117. Dodd-Frank Wall Street Reform and Consumer Protection Act, Pub. L. No. 111203, 124 Stat. 1376 (2010).

118. Whether it will succeed is disputed. See Nelson D. Schwartz \& Eric Dash, Despite Reform, Banks Have Room for Risky Deals, N.Y. TIMES, Aug. 26, 2010, at A1 (describing loopholes).

119. See Dodd-Frank Act $\S \S 201-217,124$ Stat. at $1442-520$ (to be codified at 12 U.S.C. §§ 5381-5394).

120. See Dodd-Frank Act $\S 210(\mathrm{~b})(4)(B), 124$ Stat. at 1477 (to be codified at 12 U.S.C. $\S 5390(b)(4)(B))$. Dodd-Frank affirms the Federal Deposit Insurance Corporation's power to repudiate contracts, including derivatives contracts, as long as it does so in a reasonable period of time and pays damages.

121. See Dodd-Frank Act $\S 725,124$ Stat. at 1685 (to be codified at 7 U.S.C. § 7a-1). 
It would also make trading more transparent in ways regulators could better monitor.

While a clearinghouse can be useful in important dimensions, it is unlikely to be anywhere near as helpful as the consensus in Washington came to believe during the reform discussions. ${ }^{122}$ Deep weaknesses afflict the clearinghouse, making it unwise to rely on it primarily, as Dodd-Frank has. First, it's unclear whether the exchange would itself be properly incentivized to handle counterparty risk, particularly if the major derivatives dealers themselves control the clearinghouse. ${ }^{123}$

Second, many types of derivatives just cannot be handled by a clearinghouse, because there's no market price against which the clearinghouse employees can mark the cleared but open transaction. Worse, one major class of derivatives - credit default swaps-face "jump-to-default" risk. They look fine until the underlying security has a credit event and a huge payment is due. Collateralizing these on an exchange or clearinghouse has proven to be difficult thus far, and no easy solution is available.

Third, and insidiously, a clearinghouse is a very large netting organization. It reduces risk for the participants and can enhance transparency in these financial markets. The risks netted do not disappear, but are borne by the creditors outside the exchange's netting mechanisms. If the only systemically important risks are those netted inside the exchange, fine. But if systemically important firms are outside the exchange, they bear more risk due to the exchange, and we accordingly might not reduce systemic risk enough.

Fourth, and even more insidiously, a clearinghouse ups the ante on "too big to fail," because the clearinghouse will itself be too big to fail. That's fine, but only if it doesn't fail. Recall though that fast-moving Russian exchange rates brought down Long-Term Capital Management and its Nobel Prize-winning managers. And fast-moving revaluations of subprime assets in 2008 may have moved faster than a clearinghouse would have been able to react to. If the clearinghouse can run as fast as a fast-moving market, we're safe; if it can't, we're not. $^{124}$

122. On Washington's postcrisis infatuation with clearinghouses, see COMM. ON Capital Mkts. Regulation, supra note 13, at iii-iv; U.S. Dep'T of the Treasury, FinAnCial Regulatory Reform 7 (2009); Gary Gensler, How to Stop Another Derivatives Inferno, FIN. TIMES (London), Feb. 24, 2010, http://www.ft.com/cms/s/0/3b52b642-217c11df-830e-00144feab49a.html (chair of the derivatives market's primary regulator touting capital requirements, transparency, and clearinghouses); and Michael Mackenzie, Aline Van Duyn \& Hal Weitzman, Derivatives Dealers Brace for Clearing Shake-Up, FIN. TIMEs (London), July 13, 2010, http://www.ft.com/cms/s/0/019f8048-8e9a-11df-8a67-00144feab49a .html ("After Bear Stearns and then Lehman in 2008, clearing became a priority for regulators.”).

123. See Robert E. Litan, The Derivatives Dealers' Club and Derivatives MARKETS REFORM 9, 11, 28-29 (2010), available at http://www.brookings.edu/ /media/ Files/rc/papers/2010/0407_derivatives_litan/0407_derivatives_litan.pdf.

124. See Craig Pirrong, The Economics of Clearing in Derivatives Markets: Netting, Asymmetric Information, and the Sharing of Default Risks Through a Central Counterparty (Jan. 8, 2009) (unpublished manuscript), available at http://www.ssrn.com/abstract/paper= 1340660; see also Stulz, supra note 18, at 82, 88-89; Mark J. Roe, Derivatives Clearinghouses Are No Magic Bullet, Wall St. J., May 6, 2010, at A19; Jeremy C. Kress, Credit Default Swap Clearinghouses and Systemic Risk (Apr. 3, 2010) (unpublished manuscript), available at http://ssrn.com/paper=1583912. The clearinghouse also does not address the 


\section{CONCLUSION}

Chapter 11 typically bars creditors from collecting on their loans from the bankrupt debtor, requires that creditors who preferentially seize security or get themselves repaid on the eve of bankruptcy return the assets seized or the repayment made, requires that fraudulent conveyances be recaptured by the debtor, and allows the debtor, but not the creditor, to affirm or reject outstanding contracts.

None of these rules apply to a bankrupt's derivatives and repo counterparties. Instead, derivatives and repo players can seize collateral, more widely net out gains and losses on open contracts, terminate contracts, and keep eve-ofbankruptcy preference payments from the debtor that favor them over other creditors. Their privileged capacity to jump the queue can induce a run on the failing financial institution, and such a run may have hit AIG, Bear Stearns, and Lehman, deepening and extending the recent financial crisis. Worse, their exemptions from basic bankruptcy practice can exacerbate collateral contagion and information contagion.

The systemic issues need to be analyzed in two time periods: once, for an ongoing financial crisis, and again for the years prior to the crisis. As we've seen, the impact during an ongoing crisis is indeterminate, with benefits (reducing contagion) and costs (runs, information contagion, and collateral contagion). But, the most severe bankruptcy derivatives problem is the one I've brought forward to analyze in this Article: the derivatives players' advantages undermine prebankruptcy market-discipline incentives in the years before a crisis in ways that, once a crisis hits, accelerate and transmit financial instability originating elsewhere in the financial system. That acceleration stems from the limited incentives of most derivatives counterparties to monitor the prebankruptcy debtor, to price and absorb the systemic risk, to diversify their counterparties, and to strongly insist on counterparties being well capitalized, since the derivatives and repo players do well in a resulting bankruptcy. Once they know they can seize the collateral, they monitor the collateral, not primarily the creditworthiness of the counterparty. Once they know they can obtain eve-ofbankruptcy collateral free from preference attack, they have less reason to worry early about overall counterparty risk than do less privileged creditors. Although ordinary financial creditors of the debtor see their incentives for market discipline vis-à-vis the debtor rise correspondingly, too many have only limited capacity to discipline the debtor, as often they are not well informed about that market.

knife's-edge financing issues for repos. (Repos do not go through a clearinghouse, although triparty repo, which inserts a dealer between buyer and seller, has similarities. See Garbade, supra note 99, at 38-39.)

The clearinghouse, however, has one undiscussed systemic advantage if superpriorities persist. The superpriorities' wide setoff right supports a concentrated derivatives market, because concentrated counterparties with many offsetting trades between them better capture the value of extended setoff than do decentralized traders with many counterparties. See supra Part II.B.4. The clearinghouse internalizes this setoff advantage in the clearinghouse, allowing for smaller players to indirectly get some of the Code-bestowed setoff benefit. However, the clearinghouse may itself then also pick up much, or all, of the systemic toobig-to-fail quality now adhering to major derivatives players. 
Still, even poorly informed creditors' contractual reaction could eventually reduce these problems, because in time unsecured general creditors such as those in the commercial paper market will anticipate the generality that they are bearing more risk, especially after they've suffered or seen others suffer. But the biggest unsecured creditor for financially central firms like AIG, Bear, and Lehman is the United States, as de facto guarantor of too-big-to-fail financial institutions. For the United States, localized contractual reaction is implausible, since it has no contract. Instead, regulatory reaction that motivates more market discipline is needed.

Like the mortgage-interest deduction for home ownership and our longlasting farm subsidies, we are subsidizing the production of derivatives and repos via the Code's favored treatment. When we subsidize an activity, we get more of it than we otherwise would. Worse, as economic and financial activity gravitates to the favored sector, the sector becomes more important to the economy, making change hard because it would disrupt ongoing ways of doing business. We also get vested interests who have much reason to resist change and to bring forth arguments and resources against that change.

Congress should repeal or reshape the de facto derivatives priorities in Chapter 11. A long phase-in of repeal would be needed. And, while clarifications are appropriate, such as affirming the integrated nature of an interest rate swap as not comprising two separate contracts for bankruptcy purposes, the derivatives superpriorities are far too strong, going much further than simple, principled clarifications. Although it would be better if we had good data on the magnitude of benefits and costs, without that data we must analyze incentives and make judgments as to likely reactions to changed rules. Repeal would push derivatives and repo counterparties to insist on doing business with safer debtors, would induce them to charge for the extra risk, and would help to stabilize the financial system. As weak debtors saw the costs of their repo financing and derivatives transactions rising, they would feel pressed to substitute toward longer-term, more stable financing.

My point is not that private market discipline is without qualification superior across-the-board to good, direct prudential regulation. We do not want to substitute private discipline for better public risk regulation via, say, stronger capital requirements. Rather, the point is that prudential regulation will be imperfect, because of the standard debilities of government actors and because of the potential for capture by the regulated. Indeed, some of the Code's superpriority rules now in place may represent that sort of capture. Given the debilities of prudential regulation, public efforts should be structured, if the politicaleconomy impediments to do so can be overcome, to add as much efficacious, cost-effective market discipline to the mix as we can.

The blanket exceptions and superpriorities for the derivatives and repo markets are overly broad and can let counterparties drop their guard. Given that some ex post government bailout and resolution is unavoidable, we want a bankruptcy system that encourages as much market-based, ex ante market discipline as can be had, via more market-based counterparty monitoring, better risk pricing, and more resilient financial structures. The Dodd-Frank financial reforms give the regulators significant resolution authority in a financial crisis. But they fail to harness private incentives for precrisis financial market discipline. We need to have both. 
Risk-free investments with superior bankruptcy priorities have major efficiency potential, by creating a superpriority investment channel that lowers information and negotiation costs for lender and borrower. But the priorities now come packaged with systemically dangerous government backing, because systemically central institutions heavily use the bankruptcy-safe package. When systemically central institutions use the priorities, the superpriorities' private advantages — such as saving on the costs of market discipline - are the very features that worsen systemic problems.

If Congress could separate the plainly efficient flows from those flows that are also systemically dangerous - and then restrict only the latter-it could improve the financial system in both dimensions. But if it cannot separate them for two-dimensional improvement, we need to choose between the two. We now know that the systemic costs of superpriority are very high and, to contain those costs going forward, we need to better harness market discipline in the derivatives and repo markets. To do so, Congress needs to sharply cut back the priority package. 